\title{
Cenozoic uplift of the Central Andes in northern Chile and Bolivia - reconciling paleoaltimetry with the geological evolution
}

\begin{tabular}{|r|l|}
\hline Journal: & Canadian Journal of Earth Sciences \\
\hline Manuscript ID & cjes-2015-0071.R1 \\
\hline Manuscript Type: & Article \\
\hline Date Submitted by the Author: & $14-$ Sep-2015 \\
\hline Complete List of Authors: & Lamb, Simon; Victoria University of Wellington, Institute of Geophysics \\
\hline Keyword: & $\begin{array}{l}\text { Central Andes, Cenozoic uplift, Tectonics, paleoaltimetry, Convergent plate } \\
\text { margin }\end{array}$ \\
\hline \multicolumn{2}{|l}{} \\
\hline
\end{tabular}




\title{
Cenozoic uplift of the Central Andes in northern Chile and Bolivia - reconciling paleoaltimetry with the geological evolution.
}

\author{
Simon Lamb \\ Institute of Geophysics, Victoria University of Wellington, Wellington, New Zealand \\ Simon.Lamb@vuw.ac.nz
}

\begin{abstract}
.
The Cenozoic geological evolution of the Central Andes, along two transects between $\sim 17.5^{\circ} \mathrm{S}$ and $21^{\circ} \mathrm{S}$, is compared with paleo-topography, determined from published paleo-altimetry studies. Surface and rock uplift are quantified using simple 2-D models of crustal shortening and thickening, together with estimates of sedimentation, erosion and magmatic addition. Prior to $\sim 25 \mathrm{Ma}$, during a phase of amagmatic flatslab subduction, thick skinned crustal shortening and thickening (nominal age of initiation $\sim 40 \mathrm{Ma}$ ) was focused in the Eastern and Western Cordilleras, separated by a broad basin up to $300 \mathrm{~km}$ wide and close to sea level, which today comprises the high Altiplano. Surface topography at this time in the Altiplano and the western margin of the Eastern Cordillera appears to be $\sim 1 \mathrm{~km}$ lower than anticipated from crustal thickening, which may be due to the pull-down effect of the subducted slab, coupled to the overlying lithosphere by a cold mantle wedge. Oligocene steepening of the subducted slab is indicated by the initiation of the volcanic arc at $27-25 \mathrm{Ma}$, and widespread mafic volcanism in the Altiplano between 25 and 20 Ma. This may have resulted in detachment of mantle lithosphere and possibly dense lower crust, triggering $1-1.5 \mathrm{~km}$ of rapid uplift (over $<5$ Myrs) of the Altiplano and western margin of the Eastern Cordillera and establishing the present day lithospheric structure beneath the high Andes. Since $\sim 25 \mathrm{Ma}$, surface uplift has been the direct result of crustal shortening and thickening, locally modified by the effects of erosion, sedimentation and magmatic addition from the mantle. The rate of crustal shortening and thickening varies with location and time, with two episodes of rapid shortening in the Altiplano, lasting < 5 Myrs, that are superimposed on a long term history of ductile shortening in the lower crust, driven by underthrusting of the Brazilian Shield on the eastern margin.
\end{abstract}


Keywords: Central Andes, Cenozoic uplift, Tectonics, Paleoaltimetry, Convergent plate margin.

\section{Introduction}

The uplift of large and high mountain ranges has a profound influence on our planet. With the advent of paleoaltimetry techniques, using the geomorphology of drainage systems, plant physiognomy, and geochemistry of surface deposits (see Quade et al. 2007), there have been a wealth of studies tracking the evolution of topography during the growth of Tibet, Andes, and parts of western North America. In some cases, these studies have yielded unexpected results, revealing high topography much earlier than was anticipated - for example, the Colorado Plateau (Wolf et al. 1995), Tibet (Garzione et al. 2000, Spicer et al. 2003, Wang et al. 2008), Argentinian Northern Puna (Canavan et al. 2014). Or very young km-scale uplift - for example, the Bolivian Altiplano (Garzione et al. 2006, 2008, Ghosh et al. 2006). In any case, the timing of uplift provides important constraints on the dynamical processes that cause it.

In general terms, uplift of the Earth's surface is a result of changes in the vertical density structure of the lithosphere. The largest density contrast here is between the crust and mantle, and so crustal shortening and thickening, driven by stresses that come from the interaction of the tectonic plates, is a powerful mechanism of surface uplift - the uplift will correlate closely with the amount and timing of crustal shortening, on time scales of millions to tens of millions of years. In marked contrast, numerical and theoretical models show that in certain cases an instability in the higher density and fluid-like lower part of the lithosphere can grow slowly during long term lithospheric shortening, then reach a critical stage where it rapidly detaches and sinks into the underlying hotter and lower density asthenosphere, leaving behind a thinned lithospheric mantle; isostatic rebound in the overlying crust could result in several kilometers of surface uplift, depending on the thickness of the mantle root - here, uplift post-dates shortening, and may occur on very short time scales $(<<5 \mathrm{Ma})$ (Houseman et al. 1981, Molnar et al. 1993, Molnar and Garzione 2007, Stern et al. 2013). 
Lithospheric detachment has been developed by DeCelles et al. (2009) and Ducea et al. (2011) into a general model for orogenesis, with mantle and mafic lower crustal detachment as an inevitable late stage consequence of lithospheric shortening, thereby maintaining over geological time a relatively thin lithosphere, with an intermediate to felsic crust (Rudnick 1995). However, the role of lithospheric detachment in the uplift of Tibet has become less clear, now that paleoaltimetry shows that southern Tibet has been high since at least $20 \mathrm{Ma}$, and possibly $40 \mathrm{Ma}$ (Garzione et al. 2000, Spicer et al. 2003, Wang et al. 2008). For this reason, the Central Andes is widely regarded as the best documented example of this mechanism in an actively deforming mountain belt (Garzione et al. 2008).

Following on from Lamb (2011), I test these ideas by integrating the documented Cenozoic geological evolution of the Bolivian Andes, between $\sim 17^{\circ} \mathrm{S}$ and $22^{\circ} \mathrm{S}$ with published paleo-elevation estimates, in order to determine what processes are responsible for the observed uplift. This analysis also provides insight into the large scale forces in the Earth that create large mountain ranges.

\subsection{Central Andes in northern Chile and Bolivia}

\subsubsection{Tectonic Setting}

The Central Andes in northern Chile and Bolivia form a mountain belt up to $700 \mathrm{~km}$ wide, reaching elevations greater than $6500 \mathrm{~m}$ on the western margin of South America (Fig 1). Offshore, the $~ 50$ Ma oceanic Nazca (or Farallon) plate is being subducted beneath the western margin of South America (Pardo-Casas and Molnar, 1987 ) along the Peru-Chile trench. The present day convergence is $\sim 85 \mathrm{~mm} / \mathrm{yr}$ in an ENE direction, relative to the South American plate (DeMets et al., 1994).

\subsubsection{Topography}

Figure 1a shows the topography of the Andes between $13^{\circ} \mathrm{S}$ and $23^{\circ} \mathrm{S}$. The general topographic trend of the mountainous region varies from approximately NW in the north to approximately $\mathrm{N}$ farther south, defining the Bolivian bend. Two topographic profiles, north and south of the bend, show the main topographic features (Figs. 1b, c). The western margin of the high Andes is overall steeper $\left(\sim 2^{\circ}\right)$ than the eastern margin $\left(\sim 1^{\circ}\right)$. There is also a distinct plateau in the central part, at essentially the same 
altitude north and south of the Arica bend, so that the topographic profiles have a general flat-topped hat shape.

The central plateau region is referred to as the Altiplano in Bolivia and forms a 200 $\mathrm{km}$ wide region of subdued relief, $\sim 600 \mathrm{~km}$ long in Bolivia and at an average altitude of $\sim 3800 \mathrm{~m}$, which has been essentially a sedimentary basin throughout much of the Cenozoic (Fig. 3). However, in detail, there appear to be distinct topographic highs that bound the western and eastern margins of the central plateau. The western high (referred to as the western Cordillera) is about $700 \mathrm{~m}$ higher than the Altiplano (at length scales greater than $40 \mathrm{~km}$, Figs $1 \mathrm{~b}, \mathrm{c})$. The eastern high is less than $500 \mathrm{~m}$ higher than the Altiplano at length scales greater than $40 \mathrm{~km}$, though individual peaks reach over $6000 \mathrm{~m}$ (Figs $1 \mathrm{~b}$ and $\mathrm{c}$ ). This forms the high spine of the Eastern Cordillera. The eastern flank of the Eastern Cordillera drops toward the foothills of the Andes. Here there is a marked inflection in the topographic profile, where the topography begins to flatten out (Figs. 1b, c). The eastern margin of the Andes is at altitudes of 200 to $400 \mathrm{~m}$.

This study focuses on the tectonic and magmatic evolution, and paleo-elevation history, of two transects, defined by the topographic profiles in Fig. 1a. These transects, referred to as the northern and southern profiles respectively, encapsulate the main geological features of this part of the Andes, immediately north and south of the Bolivian bend (Fig. 1). Figure 2 shows lithospheric-scale cross-sections along the northern and southern profiles.

\section{Lithospheric Profiles}

The lithospheric structure of the Central Andes is constrained by seismic receiver function analyses, combined with seismic tomography and gravity and flexural modeling (Fig. 2, Beck et al. 1996, 2002, Lyon-Caens and Molnar 1985, Watts et al. 1995, Stewart and Watts 1997, Myers et al. 1997, Yuan et al. 2000, 2002, Heit et al. 2007, Perez-Gussinye et al. 2009, Tassara and Echaurran 2012). These show that the high Andes form a broad region, $\sim 500 \mathrm{~km}$ wide, where the thick crust is up to $75 \mathrm{~km}$ thick, but the lithosphere is less than $100 \mathrm{~km}$ thick. The mantle signature of helium emissions in geothermal systems in the high Andes provides an additional constraint 
on the lithospheric structure here, because it defines the present day extent of active mantle melting, which is inferred to correspond to thin lithosphere $<100 \mathrm{~km}$ thick (Fig. 6, Hoke and Lamb 2007). The Andean lithosphere is bounded in the west by the subducted slab of the Nazca plate, and in the east by the thick lithosphere ( $>150 \mathrm{~km})$, but normal crust ( $\sim 35 \mathrm{~km}$ thick) of the Brazilian Shield (Fig. 2).

The topographic and structural trend in the northern profile is approximately NW $\mathrm{SE}$, and the high Andes are slightly narrower ( $450 \mathrm{~km}$ width for elevations $>2 \mathrm{~km}$ ) than in the southern profile ( $\sim 550 \mathrm{~km}$ width), where the trend is nearly N-S. The structural and stratigraphic evolution of the profiles is summarized in Figs. 2 - 5.

\subsection{Forearc and Western Cordillera (Volcanic Arc)}

The onshore part of the forearc rises abruptly from the coast to elevations $1-2 \mathrm{~km}$. Farther inland, a relatively smooth monoclinal ramp of Miocene (10 - $20 \mathrm{Ma})$ ignimbrites and alluvial sequences slope up from elevations of $\sim 1 \mathrm{~km}$ to $4-4.5 \mathrm{~km}$ over a distance of $\sim 50 \mathrm{~km}$, with minor faulting that accommodates shortening $<5 \mathrm{~km}$ (Figs. 1, 2a, Isacks 1988, Victor et al. 2004, Lamb et al. 1997, Jordan et al. 2010). These overly with marked angular unconformity Mesozoic and Paleozoic sequences that have undergone significant Eocene shortening (Fig. 3a, 30 - 40 Ma, Armijo et al. 2015). The active volcanic arc (Fig. 6, Western Cordillera) is about $\sim 50 \mathrm{~km}$ eastward of the western edge of the high plateau, at a base level of $4-4.5 \mathrm{~km}$ - individual arc volcanoes rise up to $2 \mathrm{~km}$ above this base level. There has been a $\sim 50 \mathrm{~km}$ eastward migration of the arc since the early Cenozoic (Campusano 1990).

\subsection{Altiplano}

The Altiplano formed a broad sedimentary basin $>200 \mathrm{~km}$ wide (Altiplano basin) during the Cenozoic, bounded by reverse faults on both margins, with up to $8 \mathrm{~km}$ of terrestrial red-bed accumulation in sub-basins (Figs. 2, 3, for example, CorqueCorocoro basin in northern profile, and Tambo Tambillo basin in southern profile). Paleocurrents show the Altiplano fluvial sequences were derived from both the Western and Eastern Cordilleras (Lamb et al. 1997, Horton and Hampton 2001, Leier 2010). Today, much of the region is covered by large salt pans, such as the Salar de 
Uyuni and Salar de Coipasa, or shallow lakes (Lago Poopo).

In the central part of the Altiplano basin, marine latest Cretaceous (Maastrichtian) limestones and shales pass up conformably into Eocene to Late Oligocene fluvial sequences, with rare interbedded volcanic tuffs (Marshall et al. 1991, Gayet et al. 1991, DeCelles and Horton 2003). Sequences become markedly conglomeratic at 25 Ma (Azurita Formation, Lamb and Hoke 1997), synchronous with the emplacement of mafic lavas and volcanic conglomerates (Kennan et al. 1995, Lamb and Hoke 1997, Hoke and Lamb 2007). On the margins of the basin, imaged in oil company seismic lines, these rest with marked angular unconformity on Mesozoic and older sequences, including Precambrian basement near the volcanic arc (Fig. 4, Troeng et al. 1994, Lamb and Hoke 1997, Lamb 2011). Large cobbles of this basement are present in the $\sim 25 \mathrm{Ma}$ Azurita Formation, outcropping in the centre of the Altiplano basin between $\sim 18^{\circ}$ and $20^{\circ} \mathrm{S}$.

The presence of frequent interbedded volcanic tuffs, together with local angular unconformities, allow tight constraints on the timing of Neogene deformation in the Altiplano, with a total of $30 \pm 10 \mathrm{~km}$ of shortening along the northern profile, and 75 $\pm 25 \mathrm{~km}$ of shortening along the southern profile (Figs. 3-5, Table 1, Bolivian Geological Survey 1978, Lavenu and Mercier 1991, Herail et al. 1993, McFadden et al. 1995, Kennan et al. 1995, Lamb and Hoke 1997, Elger et al. 2005, Lamb 2011). Altiplano tectonic shortening was markedly diachronous (Figs. 3-5), occurring $\sim 7 \mathrm{Ma}$ earlier along the southern profile (mainly between 11 and $16 \mathrm{Ma}$ ), compared to the northern profile (mainly between 5.4 and 9.5 Ma).

\subsection{Eastern Cordillera}

The Eastern Cordillera forms a rugged region east of the Altiplano that is mainly underlain by lower Paleozoic (Cambrian to Ordovician) marine sandstone and shale, up to $10 \mathrm{~km}$ thick, overlain unconformably by Cretaceous and Cenozoic marine and terrestrial deposits, up to $4 \mathrm{~km}$ thick sequences (Bolivian Geological Survey 1978, Marshall et al. 1991, Gayet et al. 1991, Rouchy et al. 1993). These have been deformed in a Paleogene fold and thrust belt since $40 \mathrm{Ma}$, with a westward vergence in the west, on the margins of the Altiplano, and eastward vergence in the east, 
towards the foreland with a total Paleogene shortening of $65-100 \mathrm{~km}$, decreasing away from the axis of the Bolivian oroclene (Fig. 2, Table 1, Bolivian Geological Survey 1978, Key 1996, 1999, Kley and Monaldi 1998, Lamb et al. 1997, Muller et al. 2002, McQuarrie 2002, Eichelberger et al. 2013). Along the northern profile, the tightly folded and thrusted Oligocene Luribay Conglomerate, together with underlying Maastrichtian and older sequences, are overlain with angular unconformity by the $28-22$ Ma Lower Salla Formation (Fig. 3a) and intruded by the $\sim 26$ Ma Illimani granitoids (Fig. 3a).

Since $\sim 27 \mathrm{Ma}$, fluvial and lacustrine sequences (with well dated volcanic tuff layers) accumulated in local compressional basins, resting with angular unconformity on deformed Late Cretaceous and Paleogene sequences (Fig. 3b, Bolivian Geological Survey 1978, Lamb et al. 1997, Horton 2005). Folding and reverse faulting of these sequences indicate that the Eastern Cordillera has undergone more-or-less continual contractional deformation during the early to mid Miocene, accommodating $30 \pm 10$ $\mathrm{km}$ of shortening, possibly with a component of dextral strike-slip, although the precise timing of shortening varies from basin to basin (Fig. 3b, Kennan et al. 1995, Lamb et al. 1997, Herail et al. 1996, Muller et al. 2002, Horton 2005, Eichelberger et al. 2013).

An essentially undeformed, although uplifted, Late Cenozoic paleodrainage system, that fed via a small number of outlets into the foreland basin farther east (Gubbels et al. 1993, Kennan et al. 1997, Barke and Lamb 2006) are preserved throughout the Eastern Cordillera at elevations $\sim 3$ to $3.7 \mathrm{~km}$ as regional peneplain remnants with thin sedimentary cover (Fig. 4, San Juan del Oro surfaces). Their existence shows that internal folding and thrusting within the Eastern Cordillera had ceased $\sim 12 \mathrm{Ma}$, although conjugate strike-slip continued and is active today (Lamb 2000, Funning et al. 2005).

\subsection{Interandean and Subandean zones}

A two-fold morpho-tectonic division is generally recognized in the Andes east of the Eastern Cordillera, comprising the Interandean zone and Subandean zone (see Kley 1996), generally at elevations $<2 \mathrm{~km}$. The Subandean zone comprises the eastern 
foothills of the Andes, generally $100-150 \mathrm{~km}$ wide at elevations $<1.5 \mathrm{~km}$, forming a NE- to E-verging fold and thrust belt that deforms late Oligocene to recent fluvial sequences. The Interandean zone lies in the transition between the mainly lower Paleozoic outcrops in the Eastern Cordillera and deformed Cenozoic sequences of the Subandean zone, coinciding with a marked reduction in average elevation in southern Bolivia. It forms a zone $50-100 \mathrm{~km}$ wide where predominantly upper Paleozoic sequences (Devonian - Carboniferous) outcrop (Bolivian Geological Survey, 1978). The structural style in the Interandean zone is similar to that in the Subandean zone, and together they were the main locus of shortening on the eastern margin of the Andes since $\sim 25 \mathrm{Ma}$, with deformation focused in the Subandean zone since $\sim 10 \mathrm{Ma}$, accommodating underthrusting of the Brazilian Shield (Fig. 1b, Kley 1996, Lamb et al. 1997, Eichelberger et al. 2013).

Total shortening in the Interandean and Subandean zone since $\sim 25 \mathrm{Ma}$ is estimated to be $120 \pm 25 \mathrm{~km}$, with $85 \pm 15 \mathrm{~km}$ since $\sim 10 \mathrm{Ma}$ (Fig. 2a, 3a, Table 1, Roeder, 1988; Herail et al., 1990; Baby et al., 1992, 1993, 1995; Wigger et al., 1993; Dunn et al., 1995, Kley and Monaldi 1998, Kley 1996, 1999, McQuarrie 2002, Uba et al. 2006, Barke and Lamb 2006, Eichelberger et al. 2013). The Brazilian Shield is overlain to the NE by a Cenozoic foreland basin up to $5 \mathrm{~km}$ thick, which thins towards the outcrop of the Brazilian shield (data held by oil companies, 1995). The latter forms the stable nucleus of this part of South America since the Proterozoic (Litherland et al., 1986).

\subsection{Magmatism}

Figures 6 shows the timing and distribution of magmatism in the Central Andes between $16^{\circ} \mathrm{S}$ and $22^{\circ} \mathrm{S}$. Volcanic activity between $\sim 26$ and $\sim 37 \mathrm{Ma}$ is rare in this part of the Andes, with the absence of a volcanic arc, interpreted to be the result of flat slab subduction in this period (James and Sacks et al. 1999, Haschke et al 2006, Hoke and Lamb 2007). Since $26 \mathrm{Ma}$, andesitic - felsic volcanic activity has been widespread across the Central Andes, extending up to $300 \mathrm{~km}$ behind the arc (Fig. 6). Early - mid Miocene (14 - 26 Ma) Sn and Ag bearing subvolcanic stocks and granitoid intrusions (Fig. 6, Haschke et al. 2006, Oncken et al. 2006, Hoke and Lamb 2007), together with major Late Miocene ignimbrite fields (Figs. 4, 6, Los Frailes 
ignimbrites, 2 - $12 \mathrm{Ma}$, and Morocoalla ignimbrites 6-9 Ma) are preserved on the western margin of the Eastern Cordillera (Schneider 1985, Baker and Francis 1978, Barke et al. 2007).

There has been mafic volcanism in the Altiplano, with the best documented periods 20 - $25 \mathrm{Ma}, 11$ - $13 \mathrm{Ma}$, and 0 - $5 \mathrm{Ma}$ (Redwood and MacIntyre 1989, Davidson et al. 1992, Hoke et al. 1993, Lamb and Hoke 1997, Elger et al. 2005, Hoke and Lamb 2007). Today, active mantle melting is occurring throughout the high Andes, resulting in degassing of mantle helium in geothermal systems and active volcanoes (Fig. 6, Hoke et al. 1994, Hoke and Lamb 2007). The early mafic volcanism (20 - $25 \mathrm{Ma})$ coincides with the onset of widespread volcanism in this part of the Andes presumably caused by slab steepening and the re-establishment of an asthenospheric corner flow beneath the high Andes - and is the most voluminous. It comprises lava flows, sills and shallow intrusive bodies that mainly outcrop on the northeastern and southeastern margins of the Salar de Uyuni (Fig. 4, 6, Tambo Tambillo, Rondal and Juliaca Formations), although sills and lavas are found in the Corque region (Azurita Formation). These are tightly folded, but originally represent 'flood basalt' type eruptions in a region up to $200 \mathrm{~km}$ long and $\sim 100 \mathrm{~km}$ wide (Fig. 5a).

\section{Paleo-altimetry}

A change in elevation of a rock outcrop is described by rock uplift $U_{r}$. However, the average change in elevation of the Earth's surface, referred to as surface uplift $U_{s}$, also depends on the average amount of vertical erosion $\mathrm{E}$ :

$$
\mathrm{U}_{\mathrm{s}}=\mathrm{U}_{\mathrm{r}}-\mathrm{E}
$$

Surface uplift is the response to changes in the isostatic equilibrium with the underlying mantle, whereas paleo-altimetry techniques, which apply to specific rock units, document rock uplift $U_{r}$. The following is a summary of the three main techniques used in the Central Andes for estimating paleo-elevation. The locations, both in space and time, of published paleoaltimetry studies are shown in Figures 2 to 4. 


\subsection{Paleofloras}

Fossil flora, preserved in volcanic or sedimentary deposits, can be used to estimate climatic conditions at the time of growth. There are broad correlations between the morphology of these flora and elevation, determined by studying living floras at different elevations and comparable climatic zones (Wolf 1995, Stranks and England 1994, Gregory 2000a, 2000b, Spicer et al. 2000). Estimates of paleo-elevation made this way have large uncertainties, generally $>1 \mathrm{~km}$, but can be used to discriminate between high $(\sim 4 \mathrm{~km})$ and low $(<2 \mathrm{~km})$ elevations. In Bolivia, there are four sites with well-studied fossil floras, currently at elevations $>3.7 \mathrm{~km}$ and ages between 6 and 20 Ma, all of which suggest elevations $>2 \mathrm{~km}$ lower when they grew (Berry 1923, Gregory 1998, Gregory 2000a, 2000b, Graham 2001).

\subsection{Paleodrainage systems}

Well preserved paleodrainage systems are indicators of regional topographic gradients at the time they were active. By comparing these gradients with present day drainage gradients, it is possible to estimate subsequent elevation changes.

Barke and Lamb (2006) quantified drainage gradients in the Late Miocene San Juan del Oro peneplain surfaces (Fig. 4), preserved at elevations of $3-3.7 \mathrm{~km}$ in the Eastern Cordillera between $17^{\circ} \mathrm{S}$ and $22^{\circ} \mathrm{S}$. By a combination of projecting these downstream to the foreland, projecting present day gradients upstream, and quantifying knickpoints in the drainage system, they showed that there had been a regional change in elevation $\left(\mathrm{U}_{\mathrm{r}}\right)$ since $\sim 8 \mathrm{Ma}$ of $1.7 \pm 0.7 \mathrm{~km}$. Taking account of $\sim 0.3$ $\mathrm{km}$ of average erosion $\mathrm{E}$ in the same time period, this indicates $1.5 \pm 0.7 \mathrm{~km}$ of surface uplift $\mathrm{U}_{\mathrm{s}}$ (see equation 1).

Jordan et al. (2010) compared the present-day slopes along the western margin of the Andes, in northern Chile between $17^{\circ} \mathrm{S}$ and $23^{\circ} \mathrm{S}$, with estimates of drainage slopes in alluvial fan systems, to determine Neogene paleo-relief of the Western Cordillera relative to the forearc. The cosmogenic flux measured in boulders preserved on $\sim 13$ Ma and older erosional surfaces indicates that the forearc has not changed significantly in elevation $(<500 \mathrm{~m})$, certainly since $\sim 13 \mathrm{Ma}$ and most likely since $\sim 25$ 
Ma (Dunai et al. 2005, Evenstar 2014 and pers. com.). So the base level used in the geomorphological analysis of Jordan et al. (2010) can be treated as essentially fixed since $\sim 25 \mathrm{Ma}$, and their relief development can be interpreted in terms of uplift relative to sea level. Thus, $2-3 \mathrm{~km}$ of the uplift of the western margin of the high Andes is likely to have occurred since $\sim 25 \mathrm{Ma}$, with $\sim 1 \mathrm{~km}$ in the last $10 \mathrm{Ma}$.

\subsection{Geochemistry of paleosols}

The ratios of carbon and oxygen isotopes in paleosol carbonates are a measure of temperature and isotopic composition of meteoric water from which the carbonates precipitated. These systematically change with altitude, and also regional and/or global climate. So any calibration for altitude needs to take account of the effects of climate change, with the assumption that the paleosols have not gone any significant alteration since they formed (Sempere et al. 2007, Quade et al. 2007). In addition, isotopic studies of modern paleosols show that there are unexplained systematic errors up to $1.5 \mathrm{~km}$ in predicted altitude, and the isotopic method can be 'blind' to elevations $<1.5 \mathrm{~km}$ (Hoke et al. 2009). This suggests that the true error in isotopic paleoaltimetry could be significantly greater than the formal errors, and most likely $>1 \mathrm{~km}$.

Figure 7 shows a $\delta^{18} \mathrm{O}$ and temperature plot for paleosols from the Bolivian Andes, using data from Garzione et al. 2006, Ghosh et al. 2006, Garzione et al. 2008, Leier et al. 2013, Garzione et al. 2014. The temperature is determined from the carbon isotopic signature (clumped $\Delta^{13} \mathrm{C}$ ) and reflects that of the soil pore waters from which the paleosol carbonates precipitated. The $\delta^{18} \mathrm{O}$ (as per mil with respect to SMOW) is that for soil waters in equilibrium with the carbonate, given the soil water temperature and the oxygen isotopic ratio in the carbonate. As noted by Quade et al. (2007), the data cluster about a curve (defined by the heavy black line in Fig. 7) that follows the general anticipated trend for $\delta^{18} \mathrm{O}$ an temperature with altitude. Altitude calibrations used by Quade et al. (2007), Ehlers and Poulsen 2009, and Garzione et al. 2014 are shown in Figure 7 by the short solid or dashed marks along the main black curve (the orientation of the marks reflects the 'trend' of the calibration elevation on the plot).

The Quade et al. (2007) calibration is based on present day variations in temperature 
and $\delta^{18} \mathrm{O}$ with elevation for the northern Bolivian Andes. The Ehlers and Poulsen (2009) calibration - referred to as the northern calibration in Figure 7 - is based on regional climate models (RCMs) which consider the effect of the Andes themselves on trajectories and precipitation of air parcels, referred to as the orogenic effect (see Leier et al. 2013). Garzione et al.'s (2014) calibration is based on a comparison with low elevation $(\sim 0.4 \mathrm{~km})$ Late Miocene $(6-12 \mathrm{Ma})$ paleosols in the eastern foothills (Subandes) of the Central Andes at $\sim 23^{\circ} \mathrm{S}$ - referred to as the southern calibration in Figure 7. There are clearly strong latitudinal effects, and the southern calibration is most applicable closest to the calibration samples at $\sim 23^{\circ} \mathrm{S}-$ it seems to progressively overpredict paleo-elevations northwards, where soil temperatures are likely to be cooler at any given elevation, with wetter conditions, as noted by Garzione et al. (2014).

In this study, the southern calibration is used for paleosols south of $20^{\circ} \mathrm{S}$ (Figs. 4, 8c, Quebrada Honda, Cerdas), and the northern calibration for paleosols farther north (Callapa, Lower and Upper Salla). For samples in the vicinity of $20^{\circ} \mathrm{S}$ (Figs. 4, 7, 8b, Quehua, Tambo Tambillo), the best estimate of paleo-elevation is taken to be somewhere between the two calibrations.

\section{Quantifying processes of surface and rock uplift}

Mechanisms for rock and surface uplift of the Bolivian Andes are: erosion, sedimentation, crustal shortening and thickening, magmatic addition to the crust, and changes in lithospheric structure such as mantle detachment (Lamb and Hoke 1997). The amount of uplift is also determined by the isostatic compensation factor $\mathrm{k}$. A comparison between observed crustal thickness and elevation in the Bolivian Andes (Beck et al. 1996, 2002, Yuan et al. 2000, 2002, Barke and Lamb 2006) indicates that $\mathrm{k}$ is in the range $5.5-7.5$, with higher values in the Eastern Cordillera, and lower values in the Altiplano (Lamb 2011).

\subsection{Uplift due to erosion, sedimentation, and magmatic addition}

Erosion will act to reduce surface uplift, but if it is not a uniform planation, it can also 
be a powerful mechanism of rock uplift. Thus, erosion $\mathrm{E}$ will reduce surface uplift by an amount $\mathrm{E} / \mathrm{k}$, but will generate rock uplift $\mathrm{E}$. (k-1)/k of relict areas; rock uplift $>1$ $\mathrm{km}$ is difficult to generate by this process as it requires very deep erosion which still leaves relict land surfaces. Geochronological data (Benjamin et al. 1987, Barnes et al. 2009) combined with direct observations of the depth of erosion from dissection and unroofing of deeper parts of the stratigraphy (Barke and Lamb 2006, Jordan et al. 2010), indicate that Neogene erosion plays only a minor role in the Western Cordillera and Altiplano. Erosion has caused 5-10 km of total unroofing in the Eastern Cordillera, with roughly equal amounts between 40 and $25 \mathrm{Ma}$, and 25 and 0 Ma.

Sedimentation has played a role in the uplift of the Altiplano. Here, an average thickness of $3-5 \mathrm{~km}$ of Cenozoic red-beds accumulated across most of the width of the Altiplano, with roughly equal amounts between 40 and $25 \mathrm{Ma}$, and 25 and $0 \mathrm{Ma}$ - surface uplift will be a factor $1 / \mathrm{k}$ of the sediment thickness. Magmatic addition is only likely to be significant on timescales of several 10s of millions of years (section 4.4, Lamb and Hoke 1997). In addition, the added material from the mantle will have a mafic composition (basalt or basaltic andesite), with a greater density $\left(2.9-3 \mathrm{~g} / \mathrm{cm}^{-3}\right.$ ) compared to average crust $\left(2.7-2.85 \mathrm{~g} / \mathrm{cm}^{-3}\right)$, and so the isostatic compensation factor $\mathrm{k} \sim 8-11$, or $1 \mathrm{~km}$ surface uplift for $8-11 \mathrm{~km}$ of added crust.

\subsection{Uplift due to crustal shortening and thickening}

In the case of pure shear crustal shortening and thickening, in 2-D vertical plane strain, uplift $\mathrm{U}_{\mathrm{s}}$ can be expressed:

$$
\mathrm{U}_{\mathrm{s}}=\Delta \mathrm{C} / \mathrm{k}-\mathrm{E}=\mathrm{S} \cdot \mathrm{C}_{\mathrm{f}} /\left(\left(\mathrm{W}_{\mathrm{f}}+\mathrm{S}\right) \cdot \mathrm{k}\right)-\mathrm{E}=\mathrm{S} \cdot \mathrm{C}_{\mathrm{i}} /\left(\mathrm{k} \cdot \mathrm{W}_{\mathrm{f}}\right)-\mathrm{E}
$$

where $\mathrm{S}$ is the observed horizontal tectonic shortening, $\mathrm{Ci}$, Wi and $\mathrm{C}_{\mathrm{f}}$, Wf are the initial and final crustal thickness and widths respectively $\left(\mathrm{S}=\mathrm{W}_{\mathrm{i}}-\mathrm{W}_{\mathrm{f}}\right), \Delta \mathrm{C}$ is the change in crustal thickness $\left(\mathrm{C}_{\mathrm{f}}-\mathrm{C}_{\mathrm{i}}\right)$, and, as before, $\mathrm{k}$ is the isostatic compensation factor, and $\mathrm{E}$ is the erosion (Lamb 2011). 


\subsubsection{Underthrusting and lower crustal shortening}

Heat flow in the high Andes (Western Cordillera, Altiplano and western margin of the Eastern Cordillera) has mean values in the range $75-100 \mathrm{mWm}^{-2}$, indicating surface geothermal gradients $\sim 35^{\circ} \mathrm{C} / \mathrm{km}$ (Springer and Forster 1998). Such a high surface geothermal gradient must inevitably result in a very weak mid to lower crust, at depths $>20 \mathrm{~km}$, even leading to lower crustal convection (Babeyko et al. 2002), especially if it has a mainly felsic composition, as indicated by the relatively low $\mathrm{P}$ wave seismic velocities (Beck et al. 2002).

Weak lower crust will be capable of undergoing significant ductile strain that is decoupled from that in the overlying brittle crust (Fig. 2), promoted by underthrusting of 'strong' lithosphere on the eastern margin, with a high Te $>50 \mathrm{~km}$ (Watts et al. 1995, Stewart and Watts 1997, Perez-Gussinye et al. 2008). Thus, surface shortening on the eastern margin of the Andes will result in uplift of the high Andes through underthrusting of the rigid foreland (Brazilian Shield) along an inclined detachment, or by ductile lower crustal shortening and thickening that is decoupled from the overlying brittle crust (Fig. 2, Lamb 2011). The latter may be described by a simple 'piston' model, in which the lower crust is squeezed and thickened by the rigid 'piston' of the underthrust lithosphere (Fig. 2, Isacks 1988, Gubbels et al. 1993, Allmendinger and Gubbels 1996, Lamb 2000, Hindle et al. 2005, Barke and Lamb 2006, Sobolev et al. 2006, Lamb 2011). In this case, for a piston of thickness $C_{p}$, underthrust a distance $S$, lower crustal shortening and thickening across a final width $\mathrm{W}_{\mathrm{f}}$ will result in surface uplift $\mathrm{U}_{\mathrm{s}}$ :

$$
\mathrm{U}_{\mathrm{s}}=\Delta \mathrm{C} / \mathrm{k}=\mathrm{C}_{\mathrm{p}} \cdot \mathrm{S} /\left(\mathrm{W}_{\mathrm{f}} \cdot \mathrm{k}\right)
$$

where, as in equation (2), $\Delta \mathrm{C}$ is the change in crustal thickness, $\mathrm{k}$ is a measure of the degree of isostatic compensation and deformation is 2-D vertical plane strain.

Where there is also brittle crustal shortening - for example, in the Altiplano and Eastern Cordillera during the Miocene - the total uplift is calculated by adding together equations (2) and (3); here equation (2) describes the contribution to uplift due to crustal thickening and erosion, and the shortening $\mathrm{S}$ in equation (3) includes all horizontal displacements in the crust. In addition, equation (3) may be modified if ductile crustal strains are not uniform along the length of the cross-section (see 
equation (4) below).

\subsubsection{Non-uniform distribution of lower crustal shortening}

The distribution of lower crustal ductile strain is unlikely to be uniform, but will depend on the rheology and physical conditions (e.g. the effects of lateral variations in temperature, pressure, stresses and composition) in the ductile zone. The sensitivity of strain rate $(\varepsilon)$ to these can be easily demonstrated with a typical flow law such as the experimental Dorn Equation (Ranalli 1995):

$$
\varepsilon=\mathrm{A} \tau^{\mathrm{n}} \exp [-(\mathrm{E}+\mathrm{pV}) / \mathrm{RT}]
$$

where $\mathrm{A}$ is a constant, $\tau$ is the deviatoric stress, $\mathrm{n}$ is the power law exponent, $\mathrm{E}$ is the activation energy of flow, $\mathrm{p}$ is the pressure, $\mathrm{V}$ is the molar volume, $\mathrm{R}$ is the universal gas constant, and $\mathrm{T}$ is the temperature in Kelvin. For example, with a wet granite rheology (for $\sim 40 \mathrm{~km}$ depth and $630^{\circ} \mathrm{C}$ reference temperature, $\mathrm{E}=137 \mathrm{~kJ} / \mathrm{mol}, \mathrm{n}=$ $1.9, \mathrm{~V}=10^{-6} \mathrm{~m}^{3} \mathrm{~mol}^{-1}$ ) indicated by the low crustal $\mathrm{P}$ velocities in the thick Altiplano crust (Beck and Zandt 2002), and the behind arc subduction setting (Ranalli 1995, Sobolev et al. 2006, Babeyko et al. 2002), increasing the mean temperature by $\sim 50^{\circ} \mathrm{C}$ would increase the strain rate by a factor of $\sim 3$ for the same deviatoric stresses, whereas a change from a wet to dry felsic rheology, or to an intermediate composition, would reduce the strain rate by at least an order of magnitude (see also discussion in Lamb 2011).

Lamb (2011) introduced an empirical constant $\gamma$, referred to as the focusing factor, which takes account of horizontal variations in ductile strain in the plane of the crosssection, when it is partitioned between several regions:

$$
\Delta \mathrm{C}(\mathrm{l})=\gamma \Delta \mathrm{C}
$$

where $\Delta \mathrm{C}(\mathrm{l})$ is the local change in crustal thickness as a consequence of ductile strain, and $\Delta \mathrm{C}$ is the average change, defined by equation (3). In order that ductile shortening balances in 2-D - i.e to preserve cross-sectional area $-\gamma$ in one region places constraints on $\gamma$ in adjacent regions. For example, if ductile shortening is partitioned 
in 2-D into regions 1 and 2, with a focusing factor $\gamma$ for region 1, then for region 2, $\gamma_{2}=(1-\gamma \alpha) /(1-\alpha)$, where $\alpha$ is the proportion of the total final region underlain by ductile strain that is within region 1 . Note that if $\gamma>1 / \alpha$, then region 2 will undergo crustal thinning and subsidence. The range of models is increased if flow of ductile lower crust out of the plane of the cross-section is also considered.

As discussed above, quite small lateral variations in composition, temperature and topographic contrasts can give rise locally to a large change in strain rate for the same driving deviatoric stresses, resulting in a local focusing factor $\gamma$ of two or more (note that elsewhere in the plane of the cross-section $\gamma<1$ to preserve cross-sectional area), although, in fact, values fairly close to $1(0.5<\gamma \leq 1.6)$ are sufficient to fit the uplift data in the Central Andes (Tables 1 and 2, and see analysis in Lamb 2011), and much more restricted than the extreme permitted values $(0 \leq \gamma<3)$ if all lower crustal shortening is focused within any particular region (assuming there is no crustal thinning).

A full analysis requires computer models of lithospheric deformation (see Sobolev et al. (2006) for a numerical simulation of the Cenozoic evolution of the Central Andes), where temperature, viscosity and stresses are calculated through time from specified boundary conditions, rheologies, rock properties and physical processes. This way, the plausibility of the values of $\gamma$ required to fit the uplift data can be directly tested.

\subsection{Uplift due to lower lithospheric detachment}

The mantle lithosphere has a higher density than the underlying asthenosphere, with a typical density contrast in the range $0.04-0.06 \mathrm{~g} / \mathrm{cm}^{-3}$ (Stern et al. 2006). For this reason, it is gravitationally unstable, and so, when weak enough, it will detach itself and sink into the underlying asthenosphere, essentially removing a vertical load from the overlying lithosphere, which will bob up in response. Simple isostasy requires a detachment of a $50-100 \mathrm{~km}$ thick layer of mantle lithosphere in order to generate an uplift of $\sim 1 \mathrm{~km}$. In addition, if the lower crust is mafic, then for crustal thicknesses $>35 \mathrm{~km}$ it is assumed to transform to eclogite (Babeyko et al. 2006), with a density $\sim 3.5 \mathrm{~g} / \mathrm{cm}^{-3}$. This will also be gravitationally unstable and could detach along with the 
underlying lithosphere. In this case, detachment of $\sim 17 \mathrm{~km}$ thick layer of pure mafic eclogite would also result in uplift of $\sim 1 \mathrm{~km}$.

In the usual geological model for mantle detachment, uplift is preceded by a slow phase of crustal and lithospheric thickening, over tens of millions of years (Houseman et al. 1981, Molnar et al. 1993, Platt and England 1993, Garzione et al. 2006). This is followed by rapid detachment of the gravitationally unstable lithospheric root, although recent dynamical models suggest that this is only likely to occur if there is an abrupt lateral change in lithospheric thickness (Stern et al. 2013). If detachment does occur, the overlying lithosphere could undergo uplift of several kilometres, and this could be on a timescale of only a few million years or less (Molnar and Garzione 2007, Stern et al. 2013).

Uplift may be enough to raise the gravitational potential energy of the lithosphere to the state where it is in deviatoric extension, and so it could be accompanied by a phase normal faulting. Also, if hot asthenosphere flows into the region left behind by the detached lithospheric root, then this would result in mantle melting through heating and adiabatic decompression, triggering a brief phase of mafic volcanism (Kay et al. 1994). Thus, an association of uplift, mafic volcanism and extension that all immediately post-dates lithospheric shortening is taken as diagnostic of this mechanism of uplift (Platt and England 1993).

\subsection{Changes in geometry of the subducted slab}

A change in the geometry of the underlying subducted slab can also generate elevation changes in the overlying lithosphere. Thus, in flat-slab or more general amagmatic subduction, the subducted plate is coupled to the overlying plate by a cold mantle wedge, and so the negative buoyancy of the subducted plate can act as a load which will pull the overlying lithosphere down $0.5-1.5 \mathrm{~km}$ (Zhong et al. 1992, Stern and Holt 1992, Kudo and Yamaoko 2003, Davila et al. 2010, Manea et al. 2012). This is in contrast to subduction above a well developed volcanic arc, where the mantle wedge consists of 'hot' and low viscosity asthenosphere.

When the load from the subducted slab is removed, the overlying plate must bob up. 
The simplest way that this can happen is by the slab sinking, creating space for an inflow of hot and low viscosity asthenospheric mantle into the overlying mantle wedge. Hydration and adiabatic decompression could result in prolific mantle melting, with the rejuvenation of the volcanic arc and widespread behind arc mafic felsic magmatism (James and Sacks 1999, Haschke et al. 2006, Hoke and Lamb 2007).

\section{Evolution of the Andean Lithosphere}

Figure 8 shows the topographic evolution of the Altiplano and Western and Eastern Cordilleras along the northern $\left(\sim 17.5^{\circ} \mathrm{S}\right)$ and southern $\left(\sim 20^{\circ} \mathrm{S}\right)$ profiles (Fig. 1a, 2), and also slightly farther south at $\sim 21^{\circ} \mathrm{S}$, based on the paleoaltimetry techniques discussed in section 3. Also shown are the major phases of shortening, as described in sections 2.1 and 2.2, the slab steepening and delamination event, inferred from the widespread and voluminous volcanism between 20 and $25 \mathrm{Ma}$ (see sections 2.5 and 5.2.2). The different methods of paleo-altimetry are clearly consistent with each other, and changes in elevation through time since $\sim 25$ Ma correlate with phases of shortening and uplift.

The initiation of Cenozoic deformation and uplift is given a nominal age of $\sim 40 \mathrm{Ma}$, when regional elevations are assumed to be close to sea level, although both the exact timing of initiation and uplift, as well initial elevation, may vary slightly from region to region. Calculated histories (within their $2 \sigma$ uncertainties) of surface and rock uplift along the northern and southern profiles for various time periods are also shown in Figure 8 and Tables 1 and 2, based on section 4 and the simple 2-D models described by equations (1) - (4), together with published estimates of the timing and amount of crustal shortening, sedimentation, erosional unroofing and magmatic addition (Benjamin et al. 1987, Lamb and Hoke 1997, Muller et al. 2002, Elger et al. 2005, Barke and Lamb 2006, Eichelberger et al. 2013, Lamb 2015).

Errors for uplift due to crustal shortening and thickening are from Monte Carlo simulations, where the statistics of multiple realisations of the data are calculated, given the range in input values (Table 1). Errors for calculated paleo-elevations are 
determined using a similar method. The values of the focusing factor $\gamma$ are chosen to provide a good fit with paleo-elevation data, in the sense that the calculated uplift trajectories lie within the formal errors of the paleo-elevation observations. As noted in section 4.2 .2 , the required values of $\gamma(0.5 \leq \gamma \leq 1.6)$ are within a significantly more restricted range than the extreme permitted values $(0 \leq \gamma<3)$ that would focus all lower crustal shortening in one particular region. In other words, it is not necessary to 'crank up' the effects of shortening with end-member crustal thickening scenarios in order to fit the paleo-elevation data within error.

Three-dimensional effects, such as the lateral flow of ductile lower crust along the length of the Andes, are not required to explain the paleo-elevation data. However, some form of large-scale change in lithospheric geometry is the most plausible explanation for the evidence of $\sim 1 \mathrm{~km}$ subsidence and abrupt uplift prior to $25 \mathrm{Ma}$ in the Altiplano and western margin of the Eastern Cordillera (section 5.2, Table 2, Fig. $8)$.

\subsection{Uplift of the Altiplano and Eastern Cordillera since $25 \mathrm{Ma}$}

Since $\sim 25 \mathrm{Ma}$, the timing and amount of crustal shortening and thickening beneath the Altiplano and Eastern Cordillera, with a smaller contribution from erosion and sedimentation, can easily explain the paleo-elevation data, within error. Accelerated episodes of uplift in the Altiplano correspond to intense phases of crustal shortening (Fig. 8a and b).

Crustal shortening in the brittle crust is generally decoupled from that in the lower crust, with lower crustal ductile shortening right across the high Andes, driven by underthrusting of the Brazilian Shield since $\sim 25 \mathrm{Ma}$, providing a long wavelength mechanism of crustal thickening and uplift (Table 1, Fig. 2). Note that the focusing factor $\gamma>0$ everywhere (see section 4.2.2), so that no areas are undergoing lower crustal thinning and extension. Thus, the paleo-elevation data is well matched along the southern profile with lower crustal flow being more focused beneath the Altiplano and Western Cordillera between $\sim 20$ and $10 \mathrm{Ma}(\gamma \sim 1.3$, Fig. 8b, Table 1) compared to beneath the Eastern Cordillera $(\gamma \sim 0.7)$, when Altiplano elevations here were 
initially $<1 \mathrm{~km}$, and there was intense brittle crustal shortening in the Altiplano. Since $\sim 10 \mathrm{Ma}$, the paleo-elevation data indicate that lower crustal flow was more focused beneath the Eastern Cordillera $(\gamma \sim 1.5$, Fig. 8b, Table 1) compared to beneath the Altiplano and Western Cordillera ( $\gamma=0.5-1$, Table 1). The situation for the northern profile is similar, except that brittle crustal shortening in the Altiplano was $\sim 7 \mathrm{Ma}$ younger, occurring between $\sim 10$ and $\sim 5 \mathrm{Ma}$ (Table 1, Fig. 8a).

\subsection{Paleogene uplift of the Altiplano and Eastern Cordillera}

The Eastern Cordillera and Altiplano were at or below sea-level in the latest Cretaceous, when marine limestones were deposited (Fig. 3a and b, Rouchy et al. 1993, Lamb et al. 1997), and so the crustal thickness was most likely similar to that in the foreland, and $\sim 35 \mathrm{~km}$ thick. Thus, Paleogene thick-skinned shortening in Eastern Cordillera, would give rise to elevations of $\sim 1.6 \mathrm{~km}$ at $\sim 25 \mathrm{Ma}$ (Tables 1 and 2).

Erosion during or after this shortening has stripped off a thickness comparable to the Paleogene sedimentary sequences deposited in the Altiplano region $(\sim 3 \mathrm{~km})$, reducing elevations by $\sim 0.5 \mathrm{~km}$ to $\sim 1.1 \mathrm{~km}(\sim 3 / \mathrm{k}$ for $\mathrm{k} \sim 6.5$, Table 2$)$. Likewise, sedimentation and shortening in the Altiplano region should cause $0.5-1 \mathrm{~km}$ of surface uplift. All these estimates are about $\sim 1 \mathrm{~km}$ higher than those indicated by paleo-altimetry studies for the Altiplano and western margin of the Eastern Cordillera (Fig. 8, Tables 1 and 2), indicating some process that is reducing elevations in these regions by this amount.

\subsubsection{Subsidence during flat slab subduction}

The virtual absence of both arc and behind-arc magmatism in the period $\sim 27$ to $37 \mathrm{Ma}$ suggests that subduction at this time took place at a low-angle, with a 'flat slab' geometry, so that there was no asthenospheric corner flow beneath the Andes - this is similar to the situation today at $28^{\circ} \mathrm{S}-33^{\circ} \mathrm{S}$, where there has been no arc and behind arc volcanism since $\sim 15 \mathrm{Ma}$ (Kay and Abruzzi 1996). As discussed in section 4.4, flat-slab subduction could provide an additional vertical load which would be enough to pull down the lithosphere beneath the Altiplano and Eastern Cordillera about $1 \mathrm{~km}$ in the Paleogene, as predicted by dynamical models of flat-slab subduction beneath relatively weak lithosphere (Fig. 10, Davila et al. 2010). 


\subsubsection{Rapid uplift with the onset of steeper subduction}

The abrupt onset of volcanism in the Bolivian Andes at $26 \mathrm{Ma}$, extending up to 300 $\mathrm{km}$ behind the arc, suggests that the asthenospheric corner flow was re-established at this time, with rapid steepening of the subducted slab (James and Sacks 1999, Haschke et al. 2006, Hoke and Lamb 2007). This would have decoupled the overlying lithosphere from the effects of the negative buoyancy of the subducted slab, resulting in $\sim 1 \mathrm{~km}$ of rapid uplift (Figs. 8,9). The paleo-elevation estimates along the northern profile for the Upper and Lower Salla Formation, between $28 \mathrm{Ma}$ and $\sim 17 \mathrm{Ma}$, appear to have captured this uplift (Fig. 8a), whereas the estimate for Tambo Tambillo Formation, at $\sim 25 \mathrm{Ma}$, along the southern profile, may be the lower 'flat slab' elevation (Fig. 8b). Subsequent uplift along the northern profile on the eastern margin of the Altiplano, between $25 \mathrm{Ma}$ and $11 \mathrm{Ma}$, can be related to crustal thickening and > $4 \mathrm{~km}$ reverse motion on the Eucalyptus Fault, which decoupled the uplift history here from the interior of the northern Altiplano, in the Corque-Corocoro basin (Fig. 8a).

Seismic, gravity and geochemical evidence point to a thin lithosphere, $90-120 \mathrm{~km}$ thick, beneath the Altiplano and western margin of the Eastern Cordillera (Fig. 2, Beck et al. 1996, 2002, Yuan et al. 2000, 2002, Myers et al. 1997, Hoke and Lamb 2007, Heit et al. 2009, Tassara and Echuarran 2012). This is also likely to be the case in the early Miocene, because REE element modeling of the $\sim 22-25$ Ma mafic volcanics in the Altiplano indicate that they are the result of mantle melting at depths between 40 and $90 \mathrm{~km}$, most plausibly in the asthenosphere (Hoke and Lamb 2007). Thus, detachment of lithospheric mantle beneath the Altiplano probably occurred during initial slab steepening, between $27-26 \mathrm{Ma}$, or during flat slab subduction between 37 and $27 \mathrm{Ma}$. In either case, detachment is likely to have been caused by the change in geometry of the subducted slab, generating the stresses that strip away the lower part of the lithosphere.

It has been suggested that mantle detachment also resulted in the loss of an eclogitic lower crust, because P-wave velocities $(<6.2 \mathrm{~km} / \mathrm{s})$ indicate a felsic crust beneath the high Andes (Beck et al. 2002). However, the felsic composition may be a much older feature of this part of the Andes, because even on the extreme eastern margin of the Eastern Cordillera, which has had no history of Cenozoic magmatism, but where the 
crust is $\sim 60 \mathrm{~km}$ thick and underthrust by the Brazilian Shield, the lower crust has $\mathrm{P}$ wave velocities $<6.2 \mathrm{kms}^{-1}$ and cannot be eclogite (Christensen and Mooney 1995, Beck et al. 2002).

\subsection{Uplift of the Western Cordillera}

The long-term evolution of topography of the Western Cordillera (volcanic arc) is most easily explained in terms of the build-up of volcanic edifices, superimposed on the effects of lower crustal shortening and thickening. The latter has pushed up or inflated the overlying brittle crust of the high Andes, driven by underthrusting farther east (Fig. 8b, Table 1). Thus, the monoclinal ramp or shoulder in the forearc, which is only broken by faults with a cumulative displacement $<2 \mathrm{~km}$ (Victor et al. 2004), marks the western edge of this ductile shortening in the lower crust (Fig. 2).

Presumably this is ultimately controlled by the thermal structure of the crust, and in particular, the geometry of the $\sim 350^{\circ} \mathrm{C}$ isotherm, defining the boundaries of lower crust that is warm enough for ductile flow (Fig. 2, Springer and Forster 1998, Lamb and Hoke 1997, Lamb 2011). A similar shoulder, marking the eastern limit of the high Andes (Whipple and Gasparini 2014), may mark the eastern edge of the region with warm ductile lower crust (Fig. 2).

The crustal thickening calculations indicate that plausible lower crustal ductile shortening beneath the Western Cordillera will result in uplift that is still $\sim 1 \mathrm{~km}$ less than required by the paleo-elevation data (Tables 1 and 2). The obvious source of additional uplift is magmatic addition to the crust beneath the arc, which has had more-or-less continual volcanism since $\sim 25 \mathrm{Ma}$ (Fig. 8b, Table 2, Francis and Hawkesworth 1994). Lamb and Hoke (1997) used the relation between topography and the thickness of the crustal root, determined from receiver function data (Beck et al. 1996), to infer that $\sim 40 \%$ of the crustal root beneath the volcanic arc $(\sim 15 \mathrm{~km}$ crustal thickness) is higher density mafic crust with a density of $3.0-3.1 \mathrm{~g} / \mathrm{cm}^{3}$. If this has accumulated since $\sim 25 \mathrm{Ma}$, when the arc was in its present location (after migrating $\sim 50 \mathrm{~km}$ eastwards since the Eocene, Campusano 1990) then it indicates magmatic addition beneath the arc at $\sim 0.6 \mathrm{~km} / \mathrm{Ma}$, contributing a total surface uplift of $1 \pm 0.5 \mathrm{~km}$ for a root density of $3.0-3.1 \mathrm{~g} / \mathrm{cm}^{-3}(15 / \mathrm{k} \mathrm{km}$ for $\mathrm{k} \sim 13)$. These simple calculations are within a factor of two of Francis and Hawkesworth's (1994) 
conservative estimate of magmatic addition beneath the arc, based on the inferred volume of intrusive volcanic rock.

Intense crustal shortening in the Western Cordillera occurred prior to $25 \mathrm{Ma}$, with folding and faulting of Paleogene and older basement sequences. In addition, paleomagnetic data suggest significant rotation of the forearc at his time, most plausibly accommodated by along strike gradients of shortening in Western Cordillera. Estimates of crustal shortening at his time are poorly constrained, but must be at least $10 \mathrm{~km}$ across a width of $100-150 \mathrm{~km}$. In this case, equation (2) predicts $>0.5 \mathrm{~km}$ of surface uplift prior to $\sim 25 \mathrm{Ma}$ (Tables 1 and 2, Fig. 9b).

\section{Discussion}

The geological and paleo-elevation data indicate that the Central Andes in Bolivia and northern Chile formed by uplift, and then merging, of two distinct mountain ranges, in the Western and Eastern Cordilleras. These were initially separated by a sedimentary basin up to $300 \mathrm{~km}$ wide and close to sea level, in what is the high Altiplano today (Lamb et al. 1997, Lamb and Hoke 1997, Armijo et al. 2015) - this also accounts for the structural style in the Eastern Cordillera, with west verging thrusts on the western margin and east verging thrusts on the eastern margin (Fig 2).

The two mountain ranges nucleated in the Paleogene ( $40 \mathrm{Ma})$, during a period of 'flat' subduction, within zones of weaker lithosphere, along the 'hot' volcanic arc (Western Cordillera) and much farther east, in the centre of a Late Cretaceous basin (Eastern Cordillera, Lamb et al. 1997, Lamb and Hoke 1997). They each had their own distinct geological evolution until $\sim 16 \mathrm{Ma}$, when the initiation of intense shortening within the intervening proto-Altiplano region eventually resulted in a single wide and high mountain range (Lamb et al. 1997, Lamb and Hoke 1997).

A crucial stage in this evolution was the development in the late Oligocene (28 to 25 $\mathrm{Ma}$ ) of thin lithosphere beneath what is today the high Andes, when it is likely that the subducted slab steepened, allowing both mantle detachment and the influx of 'hot' asthenosphere into the overlying mantle wedge. This effectively created a thermal boundary condition at the Moho, raising temperatures to close to those in the 
asthenosphere (Springer and Forster 1998). The subsequent behavior of the lithosphere can be understood in terms of its rheology and the thermal reequilibration, on a time scale of 5 - $15 \mathrm{Ma}$ (Turcotte and Schubert 1982), dictating the timing and mode of uplift, depending on the viscosity of the lower crust combined with the topographic evolution itself.

\subsection{Weak ductile lower crust}

It is clear from the analysis in this study that shortening in weak ductile lower crust has had a profound effect on the uplift of the Central Andes during the last $25 \mathrm{Ma}$. Uplift will tend to be comparable over large areas - leading to the formation of a central high plateau as the Western and Eastern Cordilleras merged - because a weak lower crust will also act as a sort of spirit level, smoothing out topographic contrasts (Fig. 2, Lamb and Hoke 1997). This mode of deformation is markedly different to thrust sheet models (for example McQuarrie 2002), in which very large rigid basement thrust sheets are postulated in the mid-lower crust beneath the Altiplano and Eastern Cordillera, transmitting thrust displacement right across the high Andes. It is hard to reconcile thrust sheet models with the plausible thermal and rheological conditions of the Andean crust (Babeyko et al. 2002, Sobolev et al. 2006).

Isostasy in an underlying weak ductile lower crust will also amplify the thickness of local sedimentary basins. This may explain why Altiplano basins are often quite narrow ( $\sim 50 \mathrm{~km}$ wide), but with very thick sediment fill $(>5 \mathrm{~km})$. Thus, the isostatic response to a sediment load depends on the density contrast between the sediment and underlying layer it is displacing. If the lower crust is weak, large and local vertical displacement of lower crust may occur, compensated by more regional lower crustal flow with a much smaller isostatic mantle response. In this case, local basin subsidence will be mainly controlled by the density contrast between the sediment load and underlying ductile lower crust, which will be much less $\left(\sim 0.2-0.3 \mathrm{~g} / \mathrm{cm}^{3}\right)$ than that with the mantle $\left(\sim 0.7 \mathrm{~g} / \mathrm{cm}^{3}\right)$. For fluvial sedimentation, sediment is replacing air, and so the amplification factor for basin depth above weak lower crust could easily be $>10$, compared to $\sim 5$ for mantle isostasy. An initial $\sim 1 \mathrm{~km}$ deep accommodation space could be rapidly filled by $>10 \mathrm{~km}$ of sediment. 


\subsection{Diachronous uplift of the Altiplano}

An interesting question is why Miocene shortening and uplift in the Bolivian Altiplano were diachronous, occurring $\sim 7$ Ma later in the vicinity of the northern profile, compared to the southern profile. This may just reflect the thermal histories of these regions. For example, if rheology of the lithosphere beneath the Bolivian Altiplano is uniform, then the central Bolivian Altiplano lithosphere heated slightly faster than that beneath northern Altiplano, so that it was weak enough by $\sim 16 \mathrm{Ma}$ to yield to the ambient stresses and undergo rapid internal strain. The northern Altiplano did not reach these conditions until $\sim 7 \mathrm{Ma}$ later. These differences in thermal history could be due to differences in the thickness of mantle lithosphere that was retained since $\sim 25 \mathrm{Ma}$ in each region.

Alternatively, the thermal history of the two regions may have been similar, but the rheologies were not uniform - for example, the northern Altiplano may have a slightly more mafic rheology compared to the central Bolivian Altiplano, so that it maintained strength for longer (Lamb 2011). In any case, the focusing factors for ductile deformation $(0.5<\gamma<1.6)$, required to explain the crustal thickening and uplift, indicate that the mechanism driving the intense Miocene shortening in the Altiplano is localized weakening of the lower crust.

\subsection{Rate of Uplift}

Advocates of the model of lithospheric detachment as a mechanism for post $25 \mathrm{Ma}$ uplift in the Central Andes tend to favour both the upper bound estimates of uplift and the lower bound estimates of the time period in which the uplift occurred, determined from isotopic paleo-elevation proxies (i.e $>3 \mathrm{~km}$ in $<<4$ Ma, Garzione et al., 2006, 2008, 2014). Thus, these authors argue that the rate of uplift is too high, when compared with observed strain rates, for crustal shortening and thickening to be the main mechanism of post $25 \mathrm{Ma}$ uplift. Instead, they have proposed separate brief events of lithospheric mantle detachment as the cause of the two phases of uplift in the Bolivian Altiplano, between 16 and $10 \mathrm{Ma}$ and 9.5 and 5.4 Ma. However, the upper bound estimates of uplift rate (e.g. Garzione et al. 2014) are no more probable 
than lower bound estimates, and the coincidence between the timing of uplift and tectonic shortening remains. Previous workers (Leier et al. 2013, Whipple and Gasparini 2014, Saylor and Norton 2014) have also argued that there is a lack of correlation between km-scale uplift and phases of crustal shortening at the same location, again indicating that mantle detachment is likely to be the main mechanism of uplift.

In this study I show that since $\sim 25 \mathrm{Ma}$, the mean values, and certainly lower bound estimates, of observed uplift can easily be accounted for both local and regional (in the lower crust) horizontal finite strains in the same time period, and so detachment is not required given the available data. The strain rates are typical of wide active plate boundary zones, with $7-15 \mathrm{~mm} / \mathrm{yr}$ across $150-200 \mathrm{~km}$, or $\sim 5 \times 10^{-8} / \mathrm{yr}$, (Lamb and Vella 1987, Lamb 2000, 2015, Flesch et al. 2007). At this strain rate, the rate of surface uplift through crustal thickening, for a final crustal thickness of $\sim 60 \mathrm{~km}$, would be $\sim 0.5 \mathrm{~mm} / \mathrm{yr}$ or $\sim 0.5 \mathrm{~km} / \mathrm{Myr}$. Lower crustal ductile strain rates can also give rise to a regional $\mathrm{km}$-scale uplift in $<5 \mathrm{Myr}$. Thus, even if rapid uplift occurs in regions without surface crustal shortening, crustal thickening at depth can still drive it.

However, given the uncertainties in both our understanding of paleo-elevations and tectonic deformation, minor episodes of detachment of small amounts of mantle lithosphere $(<25 \mathrm{~km})$ since $\sim 25 \mathrm{Ma}$, driving $<0.5 \mathrm{~km}$ of surface uplift, cannot be ruled out for the Altiplano or Eastern Cordillera (e.g. Sobolev et al. 2006). Note that some form of lithospheric detachment may have occurred farther south, beneath the Argentinian Puna, in the Late Cenozoic (Kay et al. 1994).

\section{Conclusions}

In this study, the Cenozoic geological evolution of the Central Andes, along two transects between $\sim 17.5^{\circ} \mathrm{S}$ and $21^{\circ} \mathrm{S}$, is compared with paleo-topography, determined from published paleo-altimetry studies. Surface and rock uplift are quantified using simple 2-D models of crustal shortening and thickening, together with estimates of sedimentation, erosion and magmatic addition. The principle conclusions are as follows: 
(1) Prior to $\sim 25 \mathrm{Ma}$, during a phase of amagmatic flat-slab subduction, thick skinned crustal shortening and thickening was focused in the Eastern and Western Cordilleras, separated by a broad basin up to $300 \mathrm{~km}$ wide and close to sea level, which today comprises the high Altiplano. Surface topography in the Eastern Cordillera at $\sim 25 \mathrm{Ma}$ is estimated from crustal shortening and erosion to be $\sim 1 \mathrm{~km}$, whereas paleoelevations on the western margin of the Eastern Cordillera are close to sea level. This discrepancy can be explained in terms of a local 'pull-down' effect of the subducted slab, coupled to the overlying lithosphere by a cold mantle wedge.

(2) Oligocene steepening of the subducted slab is indicated by the initiation of the volcanic arc at 27 - $25 \mathrm{Ma}$, and widespread mafic volcanism in the Altiplano between 25 and $20 \mathrm{Ma}$. This may have resulted in detachment of mantle lithosphere and possibly dense lower crust, triggering $1-1.5 \mathrm{~km}$ of rapid uplift (over $<<5 \mathrm{Myrs}$ ) of the Altiplano and western margin of the Eastern Cordillera and establishing the present day lithospheric structure beneath the high Andes.

(3) Since $\sim 25 \mathrm{Ma}$, surface uplift has been the direct result of crustal shortening and thickening, locally modified by the effects of erosion, sedimentation and magmatic addition from the mantle. The rate of crustal shortening and thickening varies with location and time, with two episodes of rapid shortening in the Altiplano, lasting $<5$ Myrs, that are superimposed on a long term history of ductile shortening in the lower crust, driven by underthrusting of the Brazilian Shield on the eastern margin.

Acknowledgements. This paper is an outcome of many years of research in the Central Andes, supported by Royal Society, NERC, BP, Shell, Exxon, EU, as part of the Oxford Andean Project. Euan Smith provided advice on quantifying uncertainties for the calculated paleo-elevation histories. This project would never have happened without the inspiration of John Dewey, who not only conceived the project in the first place, but took the risk of hiring me as a post-doc to run it, and then supported me through thick and thin over many years. I have always been inspired by both John's vast knowledge and intuition about tectonics, and his firm belief that geological problems cannot be solved without geological field work. The manuscript benefitted from the helpful reviews of Jonas Kley and Andrew Leier. 


\section{References}

Allmendinger, R. W., and Gubbels, T., 1996. Pure and simple shear plateau uplift, Altiplano-Puna, Argentina and Bolivia, Tectonophysics, 259, 1-14.

Allmendinger, R. W., Jordan, T. E., Kay, S. M., \& Isacks, B. L. (1997). The evolution of the Altiplano-Puna plateau of the Central Andes. Annual review of earth and planetary sciences, 25(1), 139-174.

Allmendinger, R. W., \& Zapata, T. R. (2000). The footwall ramp of the Subandean decollement, northernmost Argentina, from extended correlation of seismic reflection data. Tectonophysics, 321(1), 37-55.

Armijo, R., Lacassin, R., Coudurier-Curveur, A., \& Carrizo, D. (2015). Coupled tectonic evolution of Andean orogeny and global climate. Earth-Science Reviews, $143,1-35$.

Babeyko, A. Y., Sobolev, S. V., Trumbull, R. B., Oncken, O., \& Lavier, L. L. (2002). Numerical models of crustal scale convection and partial melting beneath the Altiplano-Puna plateau. Earth and Planetary Science Letters, 199(3), 373-388.

Babeyko, A.Y., Sobolev S.V., Vietor T., Oncken O., Trumbull T.B., 2006 Numerical Study of Weakening Processes in the Central Andean Back-Arc, in Oncken et al. (eds.) The Andes, Active Subduction Orogeny, Frontiers in Earth Sciences, Springer, Chapter 24, 495-512.

Baby, P., B. Guillier, J. Oller, G. Herail, D. Montemurro, and M. Specht, Structural synthesis of the Bolivian sub-Andean Zone, paper presented at 3rd International Symposium, Inst. Fr. de Rech. Sci. pour Dev. en Coop (ORSTOM), Oxford, England, 1993.

Baby, P., G. Herail, R. Salinas, and T. Sempere, Geometry and kinematic evolution of passive roof duplexes deduced from cross-section balancing: Example from the foreland thrust system of the southern Bolivian Subandean Zone, Tectonics, 11, 523-536, 1992.

Baby, P., I. Moretti, R. Guiller, R. Limachi, E. Mendez, J. Oller, and M. Specht, Petroleum System of the Northern and Central Bolivian Sub-Andean Zone, Petroleum Basins of South America, Mem. Am. Assoc. Pet. Geol., 62, 445-458, 1995. 
Baker, M., P. Francis, Upper Cenozoic volcanism in the Central Andes - ages and volumes, Earth Planet. Sci. Lett., 41, 175-187, 1978.

Barreiro, B., Jones, C. \& Lamb, S. 1998. U/Pb dating of zircons from the Quimse Cruz plutons, Bolivia. Unpublished NERC Isotope Geosciences Laboratory (NIGL) report, Keyworth, UK.

Barke, R., and Lamb S., 2006. Late Cenozoic uplift of the Eastern Cordillera, Bolivian Andes, Earth and Planetary Science Letters, 249, 350-367.

Barke, R., Lamb, S., \& MacNiocaill, C. (2007). Late Cenozoic bending of the Bolivian Andes: New paleomagnetic and kinematic constraints. Journal of Geophysical Research: Solid Earth (1978-2012), 112(B1).

Barnes, J. B., \& Ehlers, T. A. (2009). End member models for Andean Plateau uplift. Earth-Science Reviews, 97(1), 105-132.

Beck S., and Zandt G., 2002. The nature of orogenic crust in the central Andes, Journal of Geophysical Research, 107, NO. B10, 2230 doi:10.1029/2000JB000124, 2002.

Beck, S., G. Zandt, S. Myers, T. Wallace, P. Silver, and L. Drake, Crustal thickness variations in the Central Andes, Geology, 24, 407-410, 1996.

Benjamin, M., N. Johnson, and C. Naeser, Recent rapid uplift in the Bolivian Andes: Evidence from fission-track dating, Geology, 15, 680-683, 1987.

Berry, E.W., The fossil flora of Potosi, Bolivia, John Hopkins Univ. Stud. Geol., 13, 1-67, 1939.

Bolivian Geological Survey (GEOBOL) and Yacimientos Petroliferos Fiscales Bolivianos (YPFB), 1978. 1:1000,000 Mapa Geologico de Bolivia, La Paz, Bolivia.

Campusano, T.B., Kontinentale Sedimentation der Kreide und des Alttertiaers im Umfeld des subduktionsbedingten Magmatismus in der chilenischen Praekordillere (21은 $\left.23^{\circ} \mathrm{S}\right)$, Berl. Geowiss. Abh., Reihe A, 123, 1-117, 1990.

Canavan, R. R., Carrapa, B., Clementz, M. T., Quade, J., DeCelles, P. G., \& Schoenbohm, L. M. (2014). Early Cenozoic uplift of the Puna Plateau, Central Andes, based on stable isotope paleoaltimetry of hydrated volcanic glass. Geology, 42(5), 447-450.

Christensen, N. I., \& Mooney, W. D. (1995). Seismic velocity structure and composition of the continental crust: A global view. Journal of Geophysical Research: Solid Earth (1978-2012), 100(B6), 9761-9788. 
Davidson, J. P., and S.L. de Silva, S.L., Volcanic rocks from the Bolivian Altiplano: Insights into crustal structure, contamination, and magma genesis in the central Andes, Geology, 20, 1127-1130, 1992.

Dávila, F. M., Lithgow-Bertelloni, C., \& Giménez, M. (2010). Tectonic and dynamic controls on the topography and subsidence of the Argentine Pampas: The role of the flat slab. Earth and Planetary Science Letters, 295(1), 187-194.

DeCelles, P. G., \& Horton, B. K. (2003). Early to middle Tertiary foreland basin development and the history of Andean crustal shortening in Bolivia. Geological Society of America Bulletin, 115(1), 58-77.

DeCelles, P., Ducea M.N., Kapp, P., and Zandt, G., 2009, Cyclicity in Cordillera orogenic systems, Nature Geosciences, 469, 251-257 doi: 10.1038/ngeo469

DeMets, C., R.G. Gordon, D.F. Argus, and S. Stein, Current plate motions, Geophys. J. Int., 101, 425-478, 1990.

Dewey, J.F., and S.H. Lamb, Active tectonics of the Andes, Tectonophysics, 205, 7995, 1992.

Dorbath, C., M. Granet, G. Poupinet,and C. Martinez, A seismic study of the Altiplano and the Eastern Cordillera in Northern Bolivia: New constraints on a lithospheric model, paper presented at 3rd International Symposium, Int. Fr. de Rfech. Sci. pour de Dev. en Coop. (ORSTOM), Oxford, England, 1993.

Ducea, M. N. (2011). Fingerprinting orogenic delamination. Geology, 39(2), 191-192.

Dunai, T. J., López, G. A. G., \& Juez-Larré, J. (2005). Oligocene-Miocene age of aridity in the Atacama Desert revealed by exposure dating of erosion-sensitive landforms. Geology, 33(4), 321-324.

Dunn, J.F., K.G. Hartshorn, and P.W. Hartshorn, Structural styles and hydrocarbon potential of the Sub-Andean thrust belt, Petroleum Basins of South America, Mem. Am. Assoc. Pet. Geol., 62, 523-544, 1995.

Ehlers, T., Poulsen, C., 2009. Influence of Andean uplift on climate and paleoaltimetry, Earth and Planetary Science Letters, 281, 238-248.

Eichelberger, N., McQuarrie, N., Ehlers, T. A., Enkelmann, E., Barnes, J. B., \& Lease, R. O. (2013). New constraints on the chronology, magnitude, and distribution of deformation within the central Andean orocline. Tectonics, 32(5), 1432-1453.

Elger, K., Oncken, O., \& Glodny, J. (2005). Plateau $\square$ style accumulation of deformation: Southern Altiplano. Tectonics, 24(4). 
Evernden, J.F., Kriz, S.J., and Cherroni, C., 1977. Potassium - Argon ages of some Bolivian rocks, Economic Geology, 72, 1042-1061.

Evenstar, L., Stuart, F., \& Hartley, A. (2014, May). New constraints on the uplift history of the western Andes, north Chile, using cosmogenic He-3 in alluvial boulders. In EGU General Assembly Conference Abstracts (Vol. 16, p. 10998).

Funning, G. J., Barke, R. M., Lamb, S. H., Minaya, E., Parsons, B., \& Wright, T. J. (2005). The 1998 Aiquile, Bolivia earthquake: A seismically active fault revealed with InSAR. Earth and Planetary Science Letters, 232(1), 39-49.

Farrar, E., A. Clark, D. Kontak, and D. Archibald, Zongo-San Gaban Zone: Eocene foreland boundary of the Central Andean orogen, northwest Bolivia and southeast Peru, Geology, 16, 55-58, 1988.

Flesch, L.M., Holt, W.E., Haines, A.J., Wen, L., and B Shen-Tu, 2007. The dynamics of western North America: stress magnitudes and the relative role of gravitational potential energy, plate interaction at the boundary and basal tractions, 834-836. Geophys. J. Int. (2007) 169, 866-896, doi: 10.1111/j.1365-246X.2007.03274.x

Francis, P.,and C. Hawkesworth, Late Cenozoic rates of magmatic activity in the Central Andes and their relationships to continental crust formation and thickening, J. Geol. Soc. London, 151, 845-854, 1994.

Garzione, C. N., Quade, J., DeCelles, P. G., \& English, N. B. (2000). Predicting paleoelevation of Tibet and the Himalaya from $\delta 18 \mathrm{O}$ vs. altitude gradients in meteoric water across the Nepal Himalaya. Earth and Planetary Science Letters, 183(1), 215-229.

Garzione, C,N., Molnar, P., Libarkin, J.C., MacFaden, B.J., 2006. Rapid late Miocene rise of Bolivian Altiplano: Evidence for removal of mantle lithosphere, Earth and Planetary Science Letters, 241, 543-556.

Garzione, C. N., Auerbach, D. J., Smith, J. J. S., Rosario, J. J., Passey, B. H., Jordan, T. E., \& Eiler, J. M. (2014). Clumped isotope evidence for diachronous surface cooling of the Altiplano and pulsed surface uplift of the Central Andes. Earth and Planetary Science Letters, 393, 173-181.

Garzione, C.N., Hoke, G.D., Libarkin, J.C., Withers, S., MacFadden, B., Eiler, J., Ghosh, P., Mulch, A., 2008. Rise of the Andes, Science, 320, 1304-1305.

Gayet, M., L. Marshall, and T. Sempere, The Mesozoic and Palaeocene vertebrates of Bolivia and their stratigraphic context: A review in, Fossiles y facies de Bolivia, vol. 1, Rev. Tec. Yacimientos Pet. Fiscales Bolivianos, 12, 393-433, 1991. 
Gayet, M., T. Sempere, H. Cappetta, E. Jaillard, and A. Levy, La Presence de fossiles marins dans le Cretece terminal des Andes centrales et ses consequences paleogeographiques, Palaeogeogr., Palaeoclimatol., Palaeoecol., 102, 283-319, 1993.

Ghosh, P., Garzione, C.N., and Eiler, J.M., 2006. Rapid uplift of the Altiplano revealed through $13 \mathrm{C}-18 \mathrm{O}$ bonds in Paleosol carbonates, Science, 311, 511-515

Graham, A., Gregory-Wodzicki, K., Wright, K., 2001. Studies in neotropical paleobotany. XV. A Mio-Pliocene palynoflora from the Eastern Cordillera, Bolivia: implications for the uplift history of the Central Andes, Am. J. Bot. 146, 813-826.

Grant J.W., Halls C., Avial Salinas W., and Snelling N.J., 1979. K-Ar ages of igneous rocks and mineralisation in part of the Bolivian tin belt, Economic Geology, 74, 838-851.

Gregory-Wodzicki K.M., McIntosh W.C., and Velasquez K., 1998 Climatic and tectonic implications of the late Miocene Jakokkota Flora, Bolivian Altiplano. Journal of South American Earth Sciences, 11, 533 - 560.

Gregory-Wodzicki, K. M. (2000). Uplift history of the Central and Northern Andes: a review. Geological Society of America Bulletin, 112(7), 1091-1105.

Gregory-Wodzicki, K. M. (2000). Relationships between leaf morphology and climate, Bolivia: implications for estimating paleoclimate from fossil floras. Journal Information, 26(4).

Gubbels, T. L. and Isacks, B. L. and Farrar, E., 1993. High-level surfaces, plateau uplift, and foreland development, Bolivian central Andes, Geology, 21, 695-698.

Haschke M., Gunther A., Melnick D., Echtler H., Reutter K-J., Scheuber E., Oncken O., 2006. Central and Southern Andean tectonic evolution inferred from Arc magmatism, in Oncken et al. (eds.) The Andes, Active Subduction Orogeny, Frontiers in Earth Sciences, Springer, Chapter 16, 337-352.

Heit, B., Sodoudi, F., Yuan, X., Bianchi, M., \& Kind, R. (2007). An S receiver function analysis of the lithospheric structure in South America. Geophysical Research Letters, 34(14).

Herail, G., et al., Structure and kinematic evolution of Subandean thrust system of Bolivia, paper presented at 2nd International Symposium on Andean Geodynamics, Grenoble, France, 1990. 
Herail, G., P. Soler, M. Bonhomme, and J. Lizeca, Evolution geodynamique de la transition entre l'Altiplano et la Cordillere Orientale au nord d'Oruro (Bolivie) Implications sur le deroulement de l'orogenese andine, C. R. Acad. Sci., Ser. II, 317, 515-522, 1993.

Hindle D., Kley J., Oncken O., Sobolev S., 2006. Crustal balance and crustal flux from shortening estimates in the Central Andes, Earth and Planetary Science Letters 230, $113-124$.

Hoke, G.D., and Garzione, C.N., 2008, Paleosurfaces, paleoelevation, and the mechanisms for the late Miocene topographic development of the Altiplano plateau, Earth and Planet. Sci. Lett., 271, 192-201.

Hoke, G. D., Garzione, C. N., Araneo, D. C., Latorre, C., Strecker, M. R., \& Williams, K. J. (2009). The stable isotope altimeter: Do Quaternary pedogenic carbonates predict modern elevations?. Geology, 37(11), 1015-1018.

Hoke, L., and Lamb, S., 2007. Cenozoic behind-arc volcanism in the Bolivian Andes, South America: implications for mantle melt generation and lithospheric structure, Journal of the Geological Society of London, 164, 795-814.

Hoke, L., D. Hilton, S. Lamb, K. Hammerschmidt, and H. Friedrichson, ${ }^{3} \mathrm{He}$ evidence for a wide zone of active mantle melting beneath the Central Andes, Earth Planet. Sci. Lett., 128, 341-355, 1994b.

Hoke, L., S. Lamb, and J. Entenmann, Comment on Davidson, J., and S. de Silva in, Geology, 20, 1127-1130, 1993, Geology, 21, 1147-1149, 1994a.

Horton, B. K., Hampton, B. A., \& Waanders, G. L. (2001). Paleogene synorogenic sedimentation in the Altiplano plateau and implications for initial mountain building in the central Andes. Geological Society of America Bulletin, 113(11), 1387-1400.

Horton, B. K. (2005). Revised deformation history of the central Andes: Inferences from Cenozoic foredeep and intermontane basins of the Eastern Cordillera, Bolivia. Tectonics, 24(3).

Houseman, G.A., D.P. McKenzie, and P. Molner, 1981. Convective instability of a thickened boundary layer and its relevance for the thermal evolution of continental convergent belts, Journal of Geophysical Research, 86, 6115-6132.

Husson, L., Sempere, T., 2003. Thickening the Altiplano crust by gravity-driven crustal channel flow, Geophys. Res. Letts., 30, 1243, doi:10.1029/2002GL016877. 
Isacks, B., Uplift of the Central Andean Plateau and bending of the Bolivian Orocline, J. Geophys. Res., 93, 3211-3231, 1988.

James, D.E., and Sacks, I.W., Cenozoic Formation of the Central Andes. A Geophysical Perspective, In: Skinner, B. (ed.), Geology and Ore Deposits of the Central Andes, Society of Economic Geologists, Special Publ. 7, 1-25, 1999.

Jordan, T. E., Nester, P. L., Blanco, N., Hoke, G. D., Davila, F., \& Tomlinson, A. J. (2010). Uplift of the Altiplano $\square$ Puna plateau: A view from the west. Tectonics, 29(5).

Kay, S., Coira, B., and Viramonte, J., 1994. Young mafic back arc volcanics as indicators of continental lithospheric delamination beneath the Argentine Puna plateau, central Andes. J. Geophys. Res. 99, 24,323-24,339.

Kay, S. M., \& Abbruzzi, J. M. (1996). Magmatic evidence for Neogene lithospheric evolution of the central Andean "flat-slab" between $30 \mathrm{~S}$ and $32 \mathrm{~S}$. Tectonophysics, 259(1), 15-28.

Kennan L., Lamb S.H., and Rundle C., 1995. K-Ar dates from the Altiplano and Cordillera Oriental of Bolivia: implications for the Cenozoic stratigraphy and tectonics. J. of South Am. Earth Sci. 8, 163-186.

Kennan, L., S. Lamb, and L. Hoke, High altitude palaeosurfaces in the Bolivian Andes: Evidence for Late Cenozoic surface uplift in, Palaeosurfaces, Spec. Publ. Geol. Soc. London, 120, 307-324, 1997.

Kley, J. (1996). Transition from basement $\square$ involved to thin $\square$ skinned thrusting in the Cordillera Oriental of southern Bolivia. Tectonics, 15(4), 763-775.

Kley, J., \& Monaldi, C. R. (1998). Tectonic shortening and crustal thickness in the Central Andes: How good is the correlation?. Geology, 26(8), 723-726.

Kley, J. (1999). Geologic and geometric constraints on a kinematic model of the Bolivian orocline. Journal of South American Earth Sciences, 12(2), 221-235.

Kono, M., Y. Fukao, and A. Yamamoto, Mountain building in the Central Andes, $J$. Geophys. Res., 94, 3891-3905, 1989.

Kudo, T., \& Yamaoka, K., 2003. Pull-down basin in the central part of Japan due to subduction-induced mantle flow. Tectonophysics, 367(3), 203-217.

Lahsen, A., 1982. Upper Cenozoic volcanism and tectonism in the Andes of northern Chile, Earth Sci. Rev., 18, 285-302.

Lamb, S., 2000. Active Deformation in the Bolivian Andes, South America, Journal of Geophysical Research, 105, 25,627-25,653. 
Lamb, S., 2011. Did shortening in thick crust cause rapid Late Cenozoic uplift in the northern Bolivian Andes?. Journal of the Geological Society, 168(5), 1079-1092.

Lamb, S., 2015, Kinematics to dynamics in the New Zealand plate boundary zone: implications for the strength of the lithosphere, Geophysical Journal International, doi:10.1093/gji/ggv027.

Lamb, S., and Hoke, L., 1997. Origin of the high plateau in the central Andes, Bolivia, South America, Tectonics, 16, 623-649.

Lamb, S.H., and P. Vella, The last million years of deformation in part of the New Zealand plate-boundary zone, J. Struct. Geol., 9, 877-891, 1987.

Lamb, S.H., L. Hoke, L. Kennan, and J. Dewey, 1997. The Cenozoic evolution of the Central Andes in Bolivia and northern Chile in, Orogens Through Time, Spec. Publ. Geol. Soc. London, 121, 237-264.

Lavenu A., and Mercier J-L, 1991. Evolution du regime tectonique de l'Altiplano et de la Cordillere orientale des Andes de Bolivie du Miocene superior a l'Actuel: Un effet des forces de gravite et des forces aux limites, Geodynamique 6 (1), 21-55.

Leier, A. L., McQuarrie, N., Horton, B. K., \& Gehrels, G. E. (2010). Upper Oligocene conglomerates of the Altiplano, central Andes: the record of deposition and deformation along the margin of a hinterland basin. Journal of Sedimentary Research, 80(8), 750-762.

Leier, A., McQuarrie, N., Garzione, C., \& Eiler, J. (2013). Stable isotope evidence for multiple pulses of rapid surface uplift in the Central Andes, Bolivia. Earth and Planetary Science Letters, 371, 49-58.

Litherland, M., et al., The geology and mineral resources of the Bolivian Precambriam shield, Br. Geol. Sur. Overseas Mem., 9, 153 pp, 1986.

Lyon-Caen, H., P. Molnar, and G. Suarez, Gravity anomalies and flexure of the Brazilian shield beneath the Bolivian Andes, Earth Planet. Sci. Lett., 75, 81-92, 1985.

MacFadden, B. J., F. Anaya, and C. Swisher III, Neogene paleomagnetism and oroclinal bending of the central Andes of Bolivia, J. Geophy. Res., 100, 81538167, 1995.

Manea, V. C., Pérez-Gussinyé, M., \& Manea, M. (2012). Chilean flat slab subduction controlled by overriding plate thickness and trench rollback. Geology, 40(1), 35-38.

Marshall, L.G., and T. Sempere, The Eocene to Pleistocene vertebrates of Bolivia and their stratigraphic context: A review in, Fossiles y facies de Bolivia, vol. 1., Rev. 
Tec. Yacimientos Pet. Fiscales Bolivianos, 12, 631-652, 1991.

McBride, S., A. Clark, E. Farrar, and D. Archibald, Delimitation of a cryptic Eocene tectono-thermal domain in the Eastern Cordillera of the Bolivian Andes through KAr dating and 40Ar-39Ar step-heating, J. Geol. Soc. London, 144, 243-255, 1987.

McQuarrie, N., 2002. The kinematic history of the central Andean fold-thrust belt, Bolivia: Implications for building a high plateau, Bulletin of the Geological Society of America, 114, 950-963.

Miller, J.F., Granite Petrogenesis in the Cordillera Real, Bolivia and crustal evolution in the Central Andes, Ph.D thesis, Open Univ., Milton Keynes,England, 1988.

Molnar, P, England, P., Martinod, J., 1993. Mantle dynamics, uplift of the Tibetan Plateau, and the Indian monsoon. Reviews in Geophysics, 31, 357-396.

Molnar, P., and Garzione, C., 2007. Bounds on the viscosity coefficient of continental lithosphere from removal of mantle lithosphere beneath the Altiplano and Eastern Cordillera, Tectonics, 26, TC2013, doi:10.1029/2006TC001964.

Müller, J. P., Kley, J., \& Jacobshagen, V. (2002). Structure and Cenozoic kinematics of the Eastern Cordillera, southern Bolivia (21 S). Tectonics, 21(5), 1-1.

Myers, S.C., Beck, S., Zandt, G., and Wallace, T., 1998. Lithospheric-scale structure across the Bolivian Andes from tomographic images of velocity and attenuation for P and S waves. Journal of Geophysical Research, 103, 21233-21252.

Oncken, O., Hindle, D., Kley, J., Elger, K., Victor, P., \& Schemmann, K. (2006). Deformation of the central Andean upper plate system-Facts, fiction, and constraints for plateau models. In The Andes (pp. 3-27). Springer Berlin Heidelberg.

Pardo-Casas, F., and P. Molnar, Relative motion of the Nazca (Farallon) and South American plates since Late Cretaceous time, Tectonics, 6, 233-248, 1987.

Pascual, R., M.G. Vucetich, and I. Fernandez, El subgrupo Santa Barbara (grupo Salta) y sus vertebrados: Cronologia, paleoambientos, y paleobiogeografia, Proc. Congr. Geol. Argentino, VIII, San Luis, Argentina, 1981.

Platt, J., and P. England, 1993. Convective removal of the lithosphere beneath mountain belts: thermal and mechanical consequences, Am. J. Sci., 294, 307-336.

Pérez $\square$ Gussinyé, M., Lowry, A. R., Phipps Morgan, J., \& Tassara, A. (2008). Effective elastic thickness variations along the Andean margin and their relationship to subduction geometry. Geochemistry, Geophysics, Geosystems, 9(2). 
Quade, J., Garzione, C.N., and Eiler, J., 2007. Paleoelevation reconstruction using paleosol carbonates: Reviews in Mineralogy and Geochemistry, 66, 53-87.

Redwood, S.D., MacIntyre, R.M., K-Ar dating of Miocene magmatism and related epithermal mineralization of the northeastern Altiplano of Bolivia, Econ. Geol., 84, 618-630, 1989.

Riccardi, A., The Cretaceous system of southern South America, Mem. Geol. Soc. Am., 168, 161 pp, 1988.

Roeder, T., Andean-age structure of Eastern Cordillera in the province of La Paz, Bolivia, Tectonics, 7, 23-39, 1988.

Rouchy, J.M., G. Camoin, J. Casanova, and J.F. Deconinck, J.F., The central palaeoAndean basin of Bolivia (Potosi area) during the late Cretaceous and early Tertiary: reconstruction of ancient saline lakes using sedimentological, paleoecological and stable isotope records, Palaeogeogr., Palaeoclimatol., Palaeoecol., 105, 179-198, 1993.

Rudnick, R. L., 1995. Making continental crust. Nature, 378(6557), 571-577.

Saylor, J. E., \& Horton, B. K., 2014. Non-uniform surface uplift of the Andean plateau revealed by deuterium isotopes in Miocene volcanic glass from southern Peru. Earth and Planetary Science Letters, 387, 120-131.

Schildgen, T. et al. 2007. Uplift of the western margin of the Andean plateau revealed from canyon incision history, southern Peru Geology, 35, 523-526; doi: 10.1130/G23532A.1

Schneider, A., Eruptive processes, mineralisation and isotopic evolution of the Los Frailes - KariKari region, Bolivia, D.I.C. thesis, Imperial College, London, 1985.

Sempere, T., Hartley, P., Roperch, P., 2007, Comment on 'Rapid uplift of the Altiplano revealed through 13C-18O bonds in paleosol carbonates, Science, 314, $760 \mathrm{~b}$.

Sobolev S., Babeyko A., Koulakov I., Oncken, O., 2006. Mechanism of the Andean Orogeny: Insight from Numerical Modeling, in Oncken et al. (eds.) The Andes, Active Subduction Orogeny, Frontiers in Earth Sciences, Springer, Chapter 25, 513-535.

Spicer, R. A., Harris, N. B., Widdowson, M., Herman, A. B., Guo, S., Valdes, P. J., ... $\&$ Kelley, S. P. (2003). Constant elevation of southern Tibet over the past 15 million years. Nature, 421(6923), 622-624. 
Springer M., and Forster A., 1998 Heat-flow density across the Central Andean subduction zone, Tectonophysics 291, 123-139.

Stern, T. A., Quinlan, G. M., and Holt, W. E., 1992, Basin formation behind an active subduction zone: three-dimensional flexural modelling of Wanganui Basin, New Zealand, Basin Research, v. 4, p. 197 - 214.

Stern, T.A., W.R. Stratford, M.L. Salmon, 2006. Subduction at a continental margin: kinematics and dynamics of the central North Island, New Zealand, Reviews of Geophysics 44 RG4002,doi 4010.1029/2005 RG000171.

Stern, T., Houseman, G., Salmon, M., \& Evans, L., 2013. Instability of a lithospheric step beneath western North Island, New Zealand. Geology, 41(4), 423-426.

Stewart, J., \& Watts, A. B. (1997). Gravity anomalies and spatial variations of flexural rigidity at mountain ranges. Journal of Geophysical Research: Solid Earth (1978-2012), 102(B3), 5327-5352.

Stranks, L., \& England, P. (1997). The use of a resemblance function in the measurement of climatic parameters from the physiognomy of woody dicotyledons. Palaeogeography, Palaeoclimatology, Palaeoecology, 131(1), 15-28.

Tassara, T., 2005. Interaction between the Nazca and South American plates and formation of the Altiplano-Puna plateau: Review of a flexural analysis along the Andean margin $\left(15^{\circ}-34^{\circ} \mathrm{S}\right)$, Tectonophysics, 399, $39-57$.

Tassara, A., \& Echaurren, A. (2012). Anatomy of the Andean subduction zone: threedimensional density model upgraded and compared against global-scale models. Geophysical Journal International, 189(1), 161-168.

Troeng, B., E. Soria-Escalante, H. Claure, R. Mobarec, and F. Murillo, Descubrimiento de basamento precambrico en la Cordillera Occidental Altiplano de los Andes Bolivianos, Mem. congr. geol. Bolivia, XI, 231-237, 1994.

Turcotte, D., Schubert G., 1982. Geodynamics: Applications of continuum mechanics to geological problems, J. Wiley and Sons, USA, pp450.

Uba C., Heubeck C., and Hulka C., 2006. Evolution of the late Cenozoic Chaco foreland basin, Southern Bolivia Basin Research (2006) 18, 145-170, doi:10.1111/j.1365-2117.2006.00291.x

Victor, P., Oncken, O., \& Glodny, J. (2004). Uplift of the western Altiplano plateau: Evidence from the Precordillera between 20 and 21 S (northern Chile). Tectonics, 23(4).

Watts, A., S. Lamb, J. Fairhead, and J.F. Dewey, Lithospheric flexure and bending of 
the Central Andes, Earth Planet. Sci. Lett., 134, 9-21, 1995.

Wdowinski, S., R. J. O'Connell, and P.E. England, A continuum model of continental deformation above subduction zones: Application to the Andes and the Aegean. $J$. Geophys. Res., 94, 10,331-10,346, 1989.

Whipple, K. X., \& Gasparini, N. M. (2014). Tectonic control of topography, rainfall patterns, and erosion during rapid post-12 Ma uplift of the Bolivian Andes. Lithosphere, 6(4), 251-268.

Whitman, D., B. Isacks, J.-L. Chatelain, J.-M. Chiu, and A. Perez, Attenuation of high frequency sismic waves beneath the Central Andean plateau, J. Geophys. Res., 97, 19,929-19,947, 1992.

Whitman, D., Moho geometry beneath the eastern margin of the Andes, northwest Argentina: Constraints on the elastic thickness of the Andean foreland, J. Geophys. Res., 99, 15,277-15,289, 1994.

Wigger, P., et al., Variation in the crustal structure of the southern Central Andes deduced from seismic refraction investigations, in Tectonics of the Southern Central Andes, edited by K.-J. Reutter, E. Scheuber, and P. Wigger, pp 23-48, Springer-Verlag, New York, 1993.

Wolfe, J. A. (1995). Paleoclimatic estimates from Tertiary leaf assemblages. Annual Review of Earth and Planetary Sciences, 23, 119-142.

Wang, Q., Wyman, D. A., Xu, J., Dong, Y., Vasconcelos, P. M., Pearson, N., ... \& Chu, Z. (2008). Eocene melting of subducting continental crust and early uplifting of central Tibet: evidence from central-western Qiangtang high-K calc-alkaline andesites, dacites and rhyolites. Earth and Planetary Science Letters, 272(1), 158171.

Worner, G., Hammerschmidt, K., Henjes-Kunst, F., Lezaun, J., Wilke, H., Geochronology $\left({ }^{40} \mathrm{Ar} /{ }^{39} \mathrm{Ar}, \mathrm{K}-\mathrm{Ar}\right.$ and He-exposure ages) of Cenozoic magmatic rocks from Northern Chile $\left(18-22^{\circ} \mathrm{S}\right)$ : implications for magmatism and tectonic evolution of the central Andes, Revista Geologica de Chile, 27, No. 2, 205-240, 2000 .

Yang, Y., Liu, M., and Stein, S., 2003. A 3-D geodynamic model of lateral crustal flow during Andean mountain building, Geophys. Res. Letts., 30, 10.1029/2003GL038308. 
Yuan, X., Sobolev, S. V., Kind, R., Oncken, O., Bock, G., Asch, G., ... \& Comte, D. (2000). Subduction and collision processes in the Central Andes constrained by converted seismic phases. Nature, 408(6815), 958-961.

Yuan, X., Sobolev, S. V., \& Kind, R. (2002). Moho topography in the central Andes and its geodynamic implications. Earth and Planetary Science Letters, 199(3), $389-402$.

Zandt, G., A. Velasco, and S. Beck, Composition and thickness of the southern Altiplano crust, Bolivia, Geology, 22, 1003-1006, 1994. 
Table 1. Calculated and observed crustal thickening and resultant surface uplift $\left(U_{s}\right)$ in 2-D shortening models (see section 4.2) for Central Andes between $18^{\circ} \mathrm{S}$ and $21^{\circ} \mathrm{S}$, using value of focusing factor $\gamma$ that gives a good to observed paleo-elevations (see Table 2 and Fig. 8).

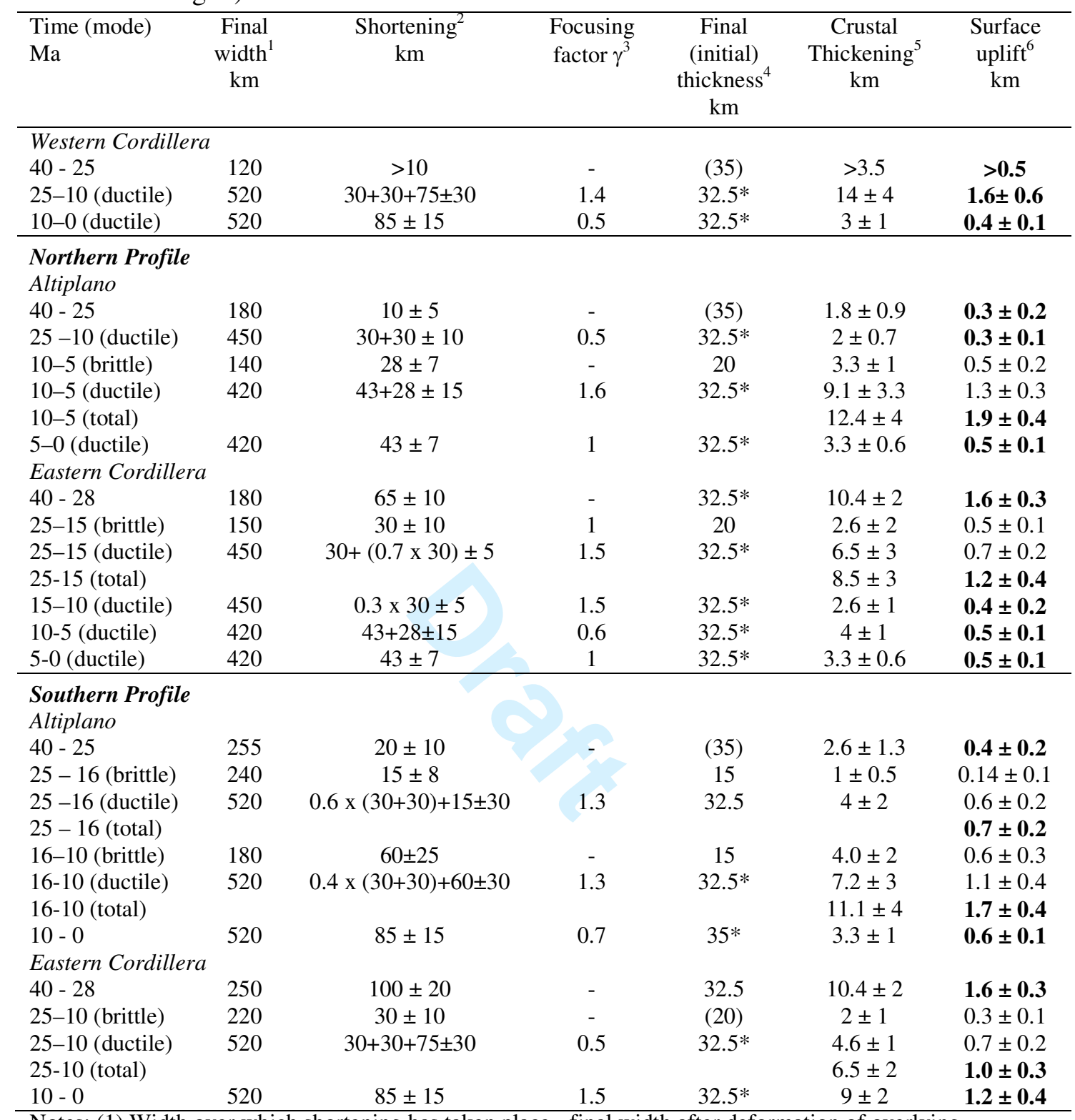

Notes: (1) Width over which shortening has taken place - final width after deformation of overlying briitle crust shown in brackets; (2) published shortening estimates for time period (after Muller et al. 2002, Elger et al. 2005, Barke and Lamb 2006, McQuarrie 2002, Lamb 2011, Eichelberger 2013); (3) best-fit focusing factor $\gamma$ for ductile strain (see section 4.2.2); (4) star denotes 'piston' thickness in lower crust, otherwise crustal thickness (section 4.2.1); (5) crustal thickening using simple 2-D crustal shortening models (equations $2-4$ in section 4.2); (6) surface uplift from shortening and thickening with $2 \sigma$ uncertainties based on Monte Carlo simulation, using isostatic factor $k=6.5 \pm 1$ (see section 4.2); values used in Table 2 shown in bold. 
Table 2. Calculated (this study, see section 4) and observed uplift for Central Andes between $18^{\circ} \mathrm{S}$ and $21^{\circ} \mathrm{S}$. Calculated paleo-elevations for representative localities shown in bold.

\begin{tabular}{|c|c|c|c|c|c|c|c|}
\hline \multirow[b]{2}{*}{$\begin{array}{l}\text { Time } \\
\mathrm{Ma}\end{array}$} & \multicolumn{5}{|c|}{ Calculated uplift during time period in $\mathrm{km}$} & \multirow[b]{2}{*}{$\begin{array}{c}\text { Paleo- } \\
\text { elevation } \\
\text { km }^{5}\end{array}$} & \multirow[b]{2}{*}{$\begin{array}{l}\text { Observed } \\
\text { rock uplift in } \\
\text { time period } \\
\text { (ref) } \mathrm{km}^{7}\end{array}$} \\
\hline & Deposition $^{1}$ & Erosion $^{1}$ & $\begin{array}{c}\text { Crustal } \\
\text { shortening }\end{array}$ & $\begin{array}{l}\text { Magmatic } \\
\text { addition3 }\end{array}$ & $\begin{array}{l}\text { Subduction/ } \\
\text { detachment }^{4}\end{array}$ & & \\
\hline \multicolumn{8}{|c|}{ Western Cordillera } \\
\hline$\sim 40$ & & & & & & 0.0 & \\
\hline $40-\sim 25$ & & & $>0.5$ & Inactive arc & $?$ & & \\
\hline$\sim 25$ & & & & & $-?$ & $1.3 \pm 0.7$ & \\
\hline $25-10$ & & & $1.6 \pm 0.6$ & $\sim 0.6$ & & $3.5 \pm 0.2$ & $2 \pm 0.5(8)$ \\
\hline $10-0$ & & & $0.4 \pm 0.1$ & $\sim 0.4$ & & 4.3 & $1.2 \pm 0.7(8)$ \\
\hline \multicolumn{8}{|c|}{ Northern Profile } \\
\hline \multicolumn{8}{|l|}{ Altiplano } \\
\hline$\sim 40$ & & & & & & 0.0 & \\
\hline $40-\sim 25$ & $0.3 \pm 0.2$ & & $0.3 \pm 0.2$ & & & $0.65 \pm 0.4$ & \\
\hline$\sim 28$ & & & & & $-1.0 \pm 0.5$ & $-0.3 \pm 0.5$ & \\
\hline$\sim 25$ & & & & & $1.0 \pm 0.5$ & $0.8 \pm 0.4$ & \\
\hline $25-10$ & $0.3 \pm 0.2$ & & $0.3 \pm 0.1$ & & & $1.4 \pm 0.4$ & $1 \pm 0.5$ \\
\hline $10-5$ & & & $1.9 \pm 0.4$ & & & $3.4 \pm 0.14$ & $2.5 \pm 1(1-3)$ \\
\hline $5-0$ & & & $0.5 \pm 0.1$ & & & 3.9 & $0.6 \pm 1$ \\
\hline \multicolumn{8}{|c|}{ Eastern margin of Altiplano and western margin of Eastern Cordillera } \\
\hline$\sim 40$ & & & & & & $\mathbf{0 . 0}$ & \\
\hline $40-28$ & & -0.5 & $1.6 \pm 0.3$ & & & $1.1 \pm 0.5$ & \\
\hline-28 & & & & & $-1.0 \pm 0.5$ & $0.1 \pm 0.5$ & \\
\hline$\sim 25$ & & & & & $1.0 \pm 0.5$ & $1.1 \pm 0.5$ & $1.5(5)$ \\
\hline $25-15$ & $0.15 \pm 0.05$ & -0.12 & $1.2 \pm 0.4$ & & & $2.35 \pm 0.4$ & $\sim 0.85(5)$ \\
\hline $15-10$ & & -0.12 & $0.4 \pm 0.2$ & & & $2.6 \pm 0.3$ & \\
\hline $10-0$ & & +0.25 & $1.0 \pm 0.2$ & & & $3.9 *$ & $1.7 \pm 0.7(7)$ \\
\hline \multicolumn{8}{|c|}{ Southern Profile } \\
\hline \multicolumn{8}{|l|}{ Altiplano } \\
\hline$\sim 40$ & & & & & & 0.0 & \\
\hline $40-\sim 25$ & $0.3 \pm 0.25$ & & $0.4 \pm 0.2$ & & & $0.7 \pm 0.5$ & \\
\hline$\sim 28$ & & & & & $-1.0 \pm 0.5$ & $-0.3 \pm 0.6$ & \\
\hline$\sim 25$ & & & & & $1.0 \pm 0.5$ & $0.6 \pm 0.5$ & \\
\hline $25-16$ & $0.3 \pm 0.25$ & & $0.7 \pm 0.1$ & & & $1.6 \pm 0.5$ & $3 \pm 0.7(4,6)$ \\
\hline $16-10$ & & & $1.7 \pm 0.6$ & & & $3.3 \pm 0.2$ & \\
\hline $10-0$ & & & $0.6 \pm 0.1$ & & & 3.9 & $0.9 \pm 1(6)$ \\
\hline \multicolumn{8}{|c|}{ Eastern Cordillera } \\
\hline$\sim 40$ & & & & & & 0.0 & \\
\hline $40-\sim 25$ & & -0.5 & $1.6 \pm 0.3$ & & & $1.1 \pm 0.5$ & \\
\hline$\sim 28$ & & & & & $(-1.0 \pm 0.5)^{6}$ & $(0.0 \pm 0.5)^{6}$ & \\
\hline$\sim 25$ & & & & & $(1.0 \pm 0.5)^{6}$ & $(1.0 \pm 0.5)^{6}$ & \\
\hline $25-10$ & & -0.25 & $1.0 \pm 0.3$ & & & $1.8 \pm 0.5$ & \\
\hline $10-0$ & & +0.25 & $1.2 \pm 0.4$ & & & $3.2 *$ & $1.7 \pm 0.7(7)$ \\
\hline
\end{tabular}

Notes: (1) Average sedimentation or erosion (sign indicates whether erosion used to calculate rock (+ve) or surface (-ve) uplift (see section 4.1); (2) see preferred 2-D shortening models in Table 1; (3) magmatic addition beneath arc based on inferred high density crustal root (see section 4.1); (4) inferred effect of mantle detachment and/or subduction pull-down, consistent with dynamical subduction models (see text); (5) Paleo-elevation of representative locality with $2 \sigma$ uncertainty at end of time period (also plotted in Fig. 8), based on data in columns to the left and assuming initial elevation at 40 Ma was sea-level (* indicates this is the elevation of an outcrop); (6) western margin of Eastern Cordillera only?; (7) estimates of rock uplift for time period from published paleo-altimetry studies using calibrations discussed in this study - see Figs. 4 and 7 -with references in brackets ( 1 = Garzione et al. 2006, 2 = Ghosh et al. 2006, 3 = Quade et al. 2007, 4 = Garzione et al. 2008, $5=$ Leier et al. 2013, $6=$ Garzione et al. 2014, $7=$ Barke and Lamb 2006, $8=$ Jordan et al. 2010). 


\section{Tables}

Table 1. Calculated and observed crustal thickening and resultant surface uplift $\left(\mathrm{U}_{\mathrm{s}}\right)$ in 2-D shortening models (see section 4.2) for Central Andes between $18^{\circ} \mathrm{S}$ and $21^{\circ} \mathrm{S}$, using value of focusing factor $\gamma$ that gives a good to observed paleo-elevations (see Table 2 and Fig. 8).

Table 2. Calculated (this study, see section 4) and observed uplift for Central Andes between $18^{\circ} \mathrm{S}$ and $21^{\circ} \mathrm{S}$. Calculated paleo-elevations for representative localities shown in bold.

\section{Figures}

Figure 1. (a) Topography of the Central Andes between $13^{\circ} \mathrm{S}$ and $22^{\circ} \mathrm{S}$, on the western margin of South America. Here, the Andes form a broad region, up to $700 \mathrm{~km}$ wide and reaching elevations of $6500 \mathrm{~m}$ asl. Virtually all this topography is the result of deformation since $\sim 40 \mathrm{Ma}$, Red lines show location of lithospheric scale profiles, analysed in this study to determine the relation between changes in paleo-topography and geological processes within the Andes. Box shows region covered by Fig. 4. (b) Topography for $50 \mathrm{~km}$ wide swath along the northern profile, showing the main physiographic provinces. Note the relatively abrupt flanks of the high Andes, where elevations $>3 \mathrm{~km}$. (c) Topography for $50 \mathrm{~km}$ wide swath along the southern profile.

Figure 2. Lithospheric-scale cross-sections along (a) the northern and (b) southern profiles (see Fig. 1 for lines of profiles). The subducted Nazca plate, dipping at $\sim 30^{\circ}$, underlies the western part of profiles, with a 'hot' overlying asthenospheric wedge where arc volcanism is generated. Also shown are main physiographic provinces, referred to in the text, the timings of crustal shortening across the width of the Andes, and the location of published paleoaltimetry studies (see Figs. 3 and 4). Note the structural vergence of major thrust structures, and the broad region beneath the Western Cordillera, Altiplano and western margin of the Eastern Cordillera that is inferred from high heat flow in thick crust to be underlain by ductile lower crust $(A L V Z=$ Altiplano Low Velocity Zone, Yuan et al. 2000). Shortening in this ductile 
crust accommodates underthrusting of the Brazilian Shield on the eastern margin, which acts as a sort of 'piston' pushing into the lower crust of the Andes farther west; crustal thickening creates the long-wavelength uplift of the high Andes since $\sim 25 \mathrm{Ma}$ (see text) - the western margin forms a monoclinal flexure, accommodating differential uplift between the Western Cordillera and Forearc. Major brittle faults in the Altiplano most plausible nucleate close to the brittle ductile transition. Note the location of published Cenozoic paleo-elevation studies discussed in the text (see Fig. 4 for explanation of reference numbers).

Figure 3. Space-time diagrams illustrating the Cenozoic geological evolution along (a) the northern and (b) southern profiles. Also shown are the stratigraphic positions of published paleo-altimetry studies. Note the presence of numerous unconformities, discrete episodes of crustal shortening in the Altiplano and Eastern Cordillera, as well as the accumulation of sedimentary sequences $5-8 \mathrm{~km}$ thick in both the Altiplano, eastern margin of the Eastern Cordillera, and Subandes, with local sedimentary basins since $\sim 25 \mathrm{Ma}$ within the Eastern Cordillera. Since $25 \mathrm{Ma}$, the Brazilian Shield has been underthrust beneath the eastern margin of the high Andes. Note the stratigraphic context of published Cenozoic paleo-elevation studies discussed in the text (see Fig. 4 for explanation of reference numbers).

Figure 4. Map showing the main geological features of the Altiplano and parts of the Eastern Cordillera between $\sim 16^{\circ} \mathrm{S}$ and $\sim 22^{\circ} \mathrm{S}$ (see box in Fig. 1a for location). The lines of the northern and southern profiles are also shown. A major fold and thrust zone, referred to as the Corque-Corocoro structure, deforms Eocene or Oligocene to Pliocene red-bed sequences, several kilometers thick, deposited in a series of subbasins (see cross-section in Fig. 5a). Deformation between $\sim 10$ and $\sim 2.7 \mathrm{Ma}$, combined with erosion and sedimentation, has uplifted and smoothed out a Middle Late Miocene paleo-depression, $0.5-1.5 \mathrm{~km}$ deep (with salar/lacustrine deposits in its centre) - the southern and northern margins of this paleo-depression are not well defined, but significant deformation prior to $\sim 10 \mathrm{Ma}$, and presumably uplift, occurred farther south at $\sim 20^{\circ} \mathrm{S}$. Farther south, Cenozoic sequences as young as $\sim 16 \mathrm{Ma}$ are tightly folded near Tambo Tambillo, and along the southeastern part of the Salar de 
Uyuni, but are unconformably ioverlain by essentially flat-lying volcanics and fluvial sequences deposited $\sim 10 \mathrm{Ma}$ (see cross-section in Fig. 5b). Note also the location of published Cenozoic paleo-elevation studies discussed in the text $(1=$ Garzione et al. 2006, 2 = Ghosh et al. 2006, 3 = Quade et al. 2007, $4=$ Garzione et al. 2008, 5 = Leier et al. 2013, $6=$ Garzione et al. 2014, 7 = Barke and Lamb 2006, $8=$ Jordan et al. 2010, $9=$ Gregory 2000, $10=$ Graham et al. 2001).

Figure 5. (a) Cross-section through the Corque-Corocoro basin (see line AA' in Fig. 4 for location), based on surface mapping and dating studies, and an interpretation of oil company seismic data (with kind permission of Yacimientos Petroliferos Fiscales Bolivianos, and see also Lamb and Hoke 1997, Lamb 2011). The structure forms a regional syncline, bounded by NE and SW verging thrusts that cut red-bed sequences as young as $\sim 5 \mathrm{Ma}$. The regional dips outside the structure point to an underlying SW-verging thrust, possibly soling in the brittle-ductile transition at $15-20 \mathrm{~km}$ depth. See Lamb (2011) for seismic data used to constrain parts of the cross-section. Note the part of the syncline, projected along strike from the north (see Fig. 5a), sampled for isotope paleo-altimetry studies (Garzione et al. 2006, Ghosh et al. 2006). (b) Cross-section through the Tambo Tambillo region (see line BB' in Fig. 4, and also Lamb and Hoke 1997). Note the tight concentric fold structure, with subvertical, or overturned limbs. A regional extensive $\sim 23 \mathrm{Ma}$ basaltic sill and mafic to felsic volcanics, with overlying red beds as young as $\sim 16 \mathrm{Ma}$, are tightly folded in the core of the Tambo Tambillo syncline.

Figure 6. Shaded topographic map of the Central Andes, between $13^{\circ} \mathrm{S}$ and $23^{\circ} \mathrm{S}$, showing the location of Cenozoic volcanic provinces, as well as the region, covering most of the high Andes, with detectable mantle helium emissions in geothermal systems ( $>0.5 \mathrm{R} / \mathrm{Ra}$, Hoke and Lamb 2007). The latter indicates the extent of active mantle melting, most plausibly marking the region with thin lithosphere today (Hoke and Lamb 2007). Note the location of the profiles analysed in this study (thick grey lines), and the active volcanic arc, following the western margin of the high Andes. Felsic to intermediate shallow level intrusions, volcanic stocks, and ignimbrites, emplaced or erupted between 26 and $2 \mathrm{Ma}$, are found on the western margin of the Eastern Cordillera, more-or-less within the region of active mantle melting indicated 
by helium emissions - magmatic activity here prior to $\sim 26 \mathrm{Ma}$ is rare. (b) Plot of age against distance perpendicular to the active arc of Neogene volcanic and plutonic rocks in the Andes between $16^{\circ}$ and $22^{\circ} \mathrm{S}$ (compiled from Everden et al. 1977, Grant et al. 1978, Schneider 1985, Redwood and MacIntyre 1989, Kennan et al. 1995, Barreiro 1998, Woerner et al. 2000, Barke 2004, Hoke and Lamb 2007). EC = Eastern Cordillera. Arc and widespread behind arc volcanism started abruptly at $\sim 26 \mathrm{Ma}$, after a $\sim 10$ Ma period of arc quiescence. Since then, there has been more-or-less continual felsic to mafic volcanism extending up to $\sim 300 \mathrm{~km}$ behind the arc. Note the $\sim 50 \mathrm{~km}$ westward migration of the eastern limit of magmatism. Also plotted is normalised $3 \mathrm{He} / 4 \mathrm{He}$ in geothermal emissions along the southern profile, showing the pronounced mantle helium signature right across the high Andes, in the same region where there is behind arc dacitic-rhyolitic volcanism. This strongly suggests that the heat source for this volcanism is mantle melts at depth in the crust, which only occasionally erupt at the surface as basalts.

Figure 7. Published oxygen isotope and growth temperature data for water in equilibrium with Cenozoic (28 - $5 \mathrm{Ma}$ ) paleosol carbonates in the Bolivian Andes, at sites with elevations ranging between 3.7 and $3.9 \mathrm{~km}$ (see Figs. 2, 3, 4 for locations, Ghosh et al. 2006, Garzione et al. 2006, 2008, Leier et al. 2013, Garzione et al. 2014). Data show a marked trend, indicated by bold line, from 'high' temperature and 'heavy' oxygen isotopes to 'low' temperatures and 'light' oxygen, relative to SMOW. This trend also reflects a general increase in paleo-elevation, although the precise paleo-elevation depends on the calibration used. Short lines (heavy, dashed, thin dashed) show the inferred paleo-elevations along the trend line, using the calibrations of Quade et al. (2007), Ehlers and Poulsen (2009), and Garzione et al. (2014). Garzione et al.'s (2014) calibration is referred to as the southern calibration (Fig. 8), as it depends on a comparison with low elevation $(\sim 0.4 \mathrm{~km})$ Late Miocene paleosols at $\sim 23^{\circ} \mathrm{S}$, whereas Ehlers and Poulsen's (2009) is referred to as the northern calibration.

Figure 8. Plots showing the elevation evolution for parts of the high Andes along (a) the northern profile at $\sim 17.5^{\circ} \mathrm{S}$, (b) southern profile at $\sim 20^{\circ} \mathrm{S}$, and (c) slightly farther south at $\sim 21^{\circ} \mathrm{S}$. Paleo-elevations from published paleo-altimetry studies are plotted, using either the northern or southern calibrations shown in Fig. 7. Coloured lines 
show uplift trajectories (with $2 \sigma$ uncertainties), calculated in this study for different regions $($ green $=$ Western Cordillera, red $=$ Altiplano, blue $=$ Eastern Cordillera $)$, based on published estimates of crustal shortening (using 'best-fit' values of the focusing factor $\gamma$ in Tables 1 and 2), erosion, sedimentation and magmatic addition, together with inferred subsidence/uplift between between 28 and 25 Ma related to changes in lithospheric geometry (see Tables 1 and 2, and section 4). Note that the calculated trajectory at $21^{\circ} \mathrm{S}$ for the Eastern Cordillera since $\sim 25 \mathrm{Ma}$ has but shifted upward $300 \mathrm{~m}$ to match the modern day elevation; the one for the Altiplano is the same as that for $20^{\circ} \mathrm{S}$.

Figure 9. A series of cartoons illustrating the inferred lithospheric evolution for the Central Andes between $16^{\circ}$ and $21^{\circ} \mathrm{S}$. (a) In the Paleocene ( 60 Ma), volcanic activity was mainly confined to the arc, with a broad region behind (east of) the arc, $>400 \mathrm{~km}$ wide, of subsidence. Deformation and uplift in the behind arc region commenced at $\sim 40 \mathrm{Ma}$. (b) Between $\sim 37$ - 26 Ma, arc volcanism shut off, most likely caused by the flattening of the subducted slab. This way, the negative buoyancy of the subducted slab 'pulled down' the overlying lithosphere $\sim 1 \mathrm{~km}$, counteracting much of the elevation increase due to crustal thickening. The Altiplano formed a wide region, close to sea level, between the arc (Western Cordillera) and 'low' Eastern Cordillera. (c) Significant Andean lithospheric shortening in the Eastern Cordillera and Altiplano ceased at $\sim 28 \mathrm{Ma}$. Arc volcanism, together with widespread behind arc mafic - felsic volcanism, resumed abruptly at $\sim 26 \mathrm{Ma}$, most plausibly triggered by creation of an asthenosphere wedge as the subducted slab steepened (possibly with detachment of the lower part of the lithosphere). This decoupled the Andean lithosphere from the subducted plate, resulting in $\sim 1 \mathrm{~km}$ of rapid uplift and the creation of thin lithosphere beneath the high Andes, which subsequently has remained largely unchanged. (d) Intense shortening was focused beneath the Altiplano, with rapid episodes, lasting $<5$ Myrs, in the northern Bolivian Altiplano (along the northern profile) between $\sim 9.5$ and $\sim 5.4 \mathrm{Ma}$, and in the central Altiplano (along the southern profile) between $\sim 16$ and $10 \mathrm{Ma}$. This, together with lower crustal ductile shortening beneath most of the width of the high Andes, driven by underthrusting of the Bolivian Shield on the eastern margin, resulted in $\mathrm{km}$-scale uplift of the high Andes so that the Western 
(volcanic arc) and Eastern Cordilleras merged. Widespread behind arc mafic - felsic volcanism was more-or-less continuous throughout this period (see Fig. 6b). 

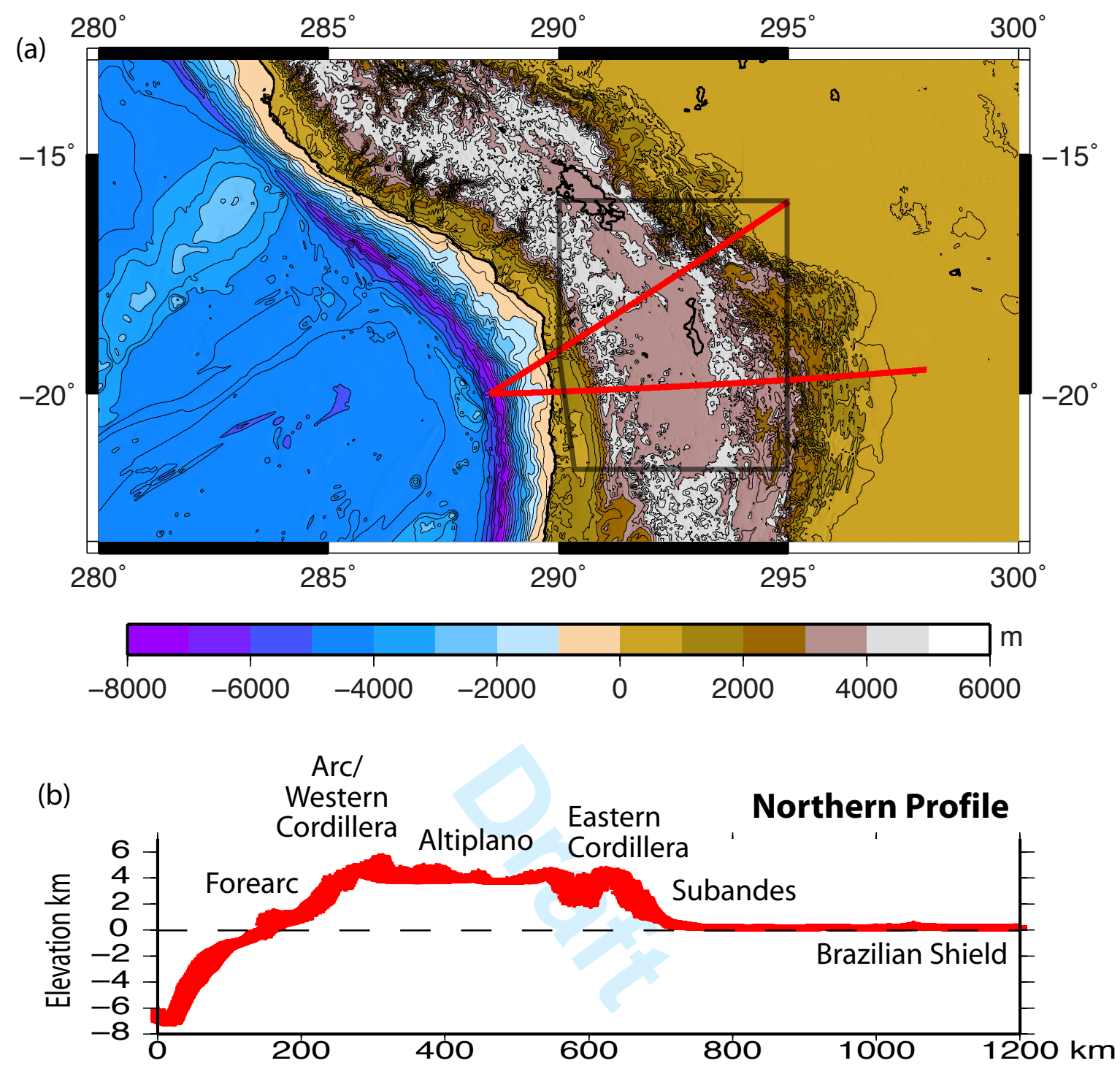

Arcl

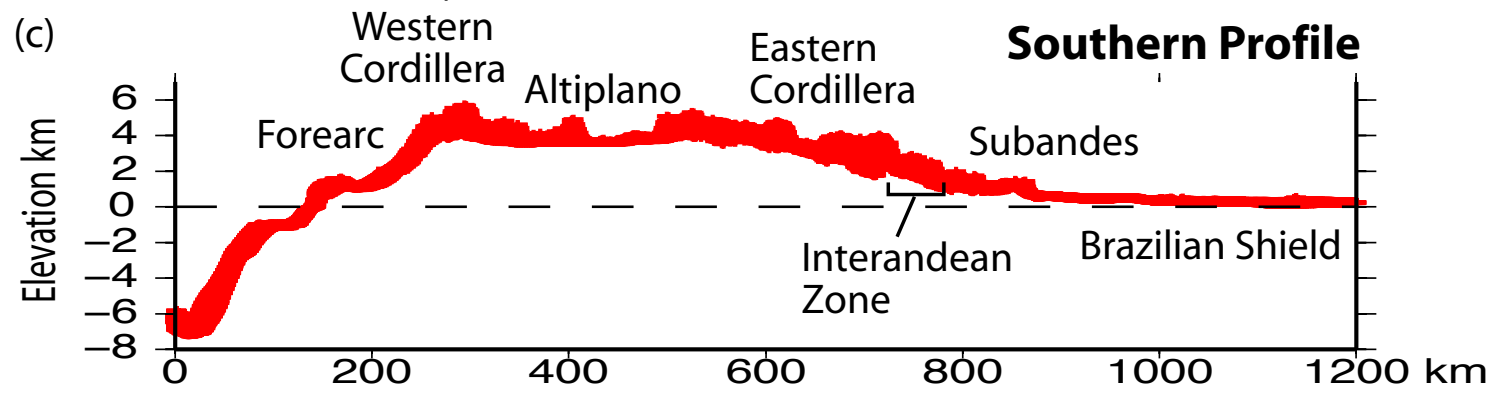




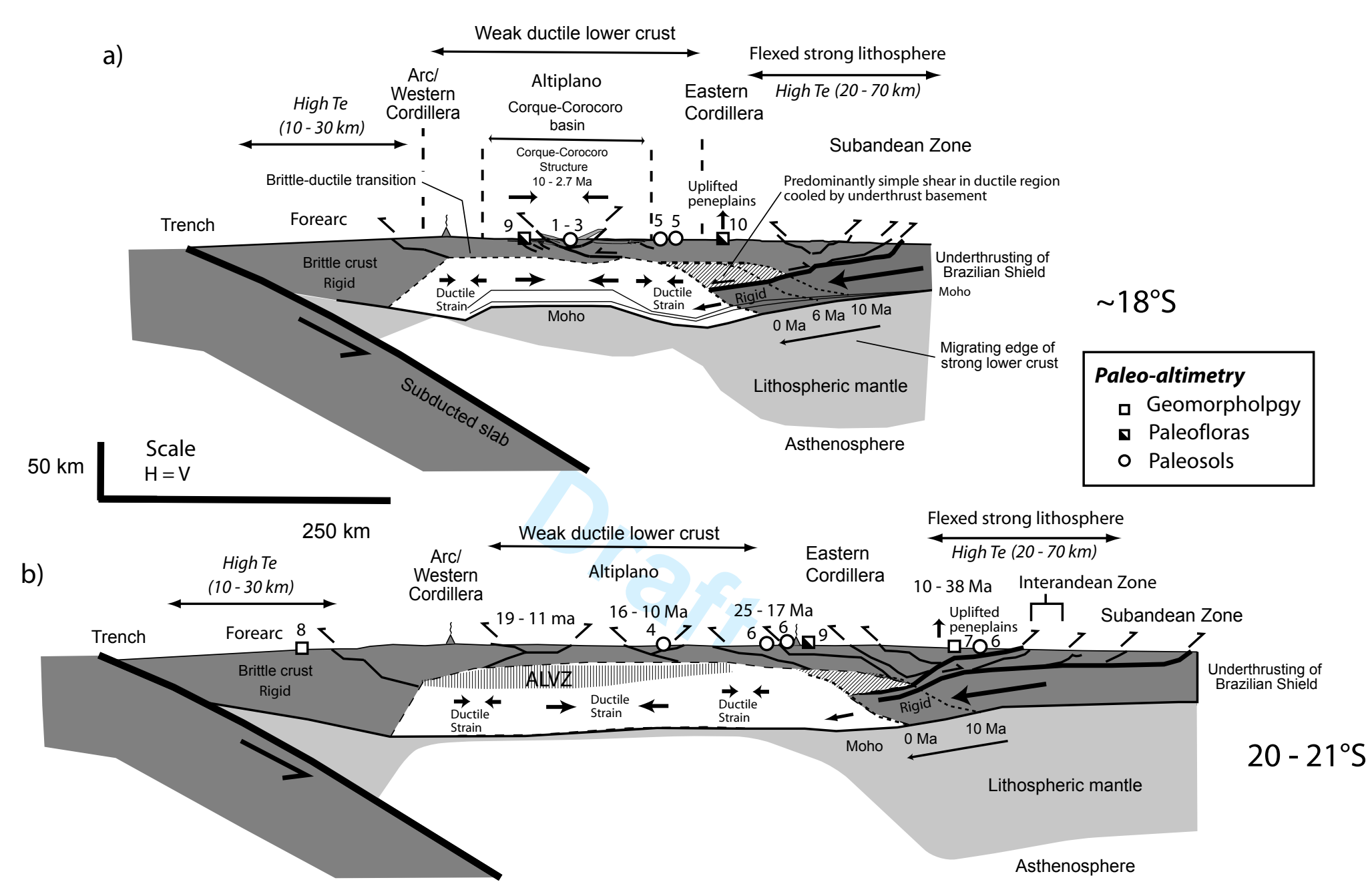



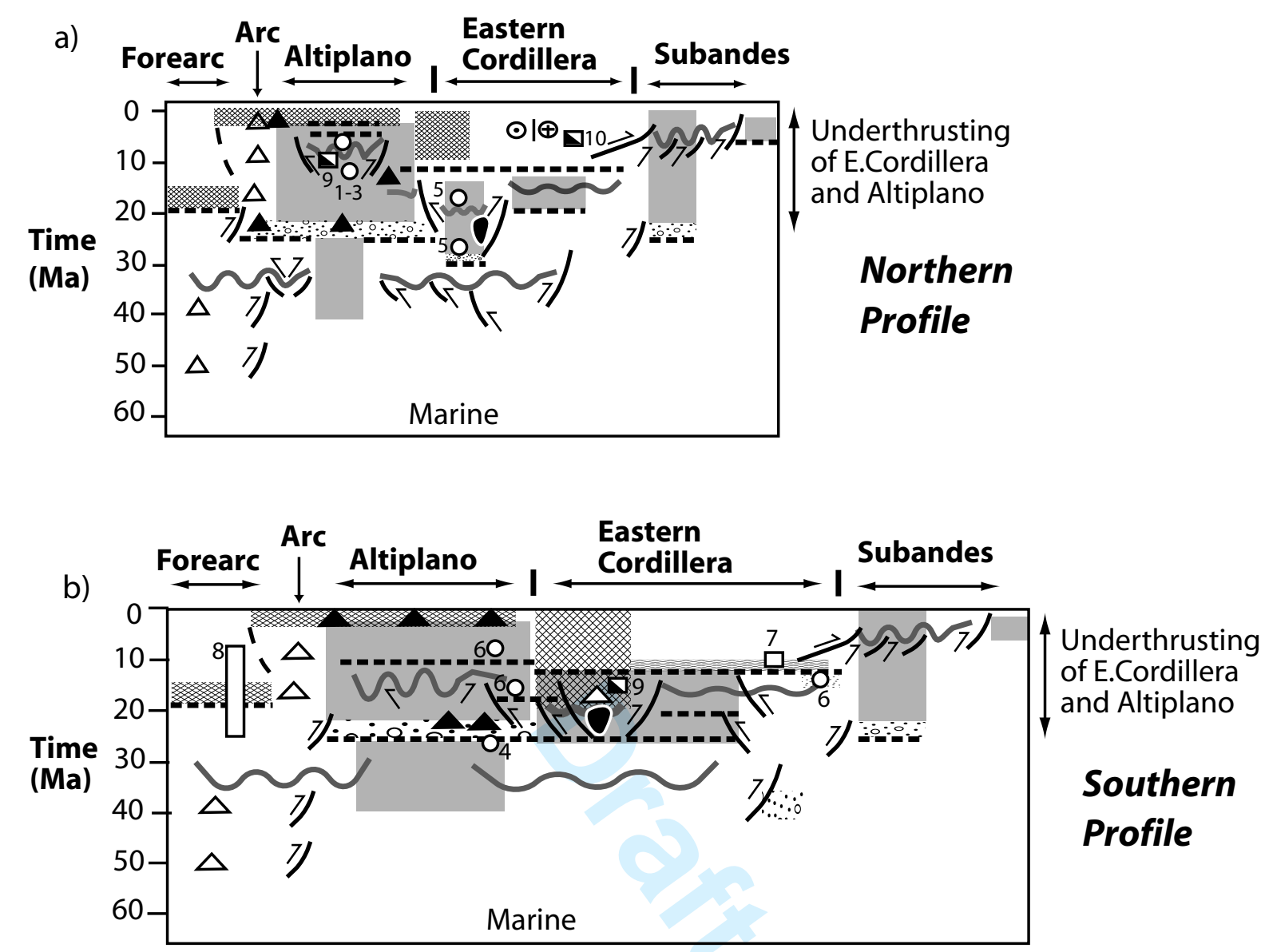

\begin{tabular}{|c|c|c|}
\hline $\begin{array}{l}\begin{array}{l}\text { Fluvial } \\
\text { /Lacustrine } \\
\text { facies }\end{array} \\
\text { Paleoaltimetry indicatc }\end{array}$ & $\begin{array}{lll} & \text { Proximal fluvial } \\
\text { onformity } & \text { Regi } \\
& \text { alluvial facies }\end{array}$ & lal folding 7/ Thrusting \\
\hline $\begin{array}{l}\square \quad \text { Geomorphology } \\
\text { Magmatism }\end{array}$ & D Paleofloras $\bigcirc$ & Paleosols \\
\hline$\triangle$ Arc type volcanism & A Mafic volcanism & Silicic intrusions \\
\hline
\end{tabular}




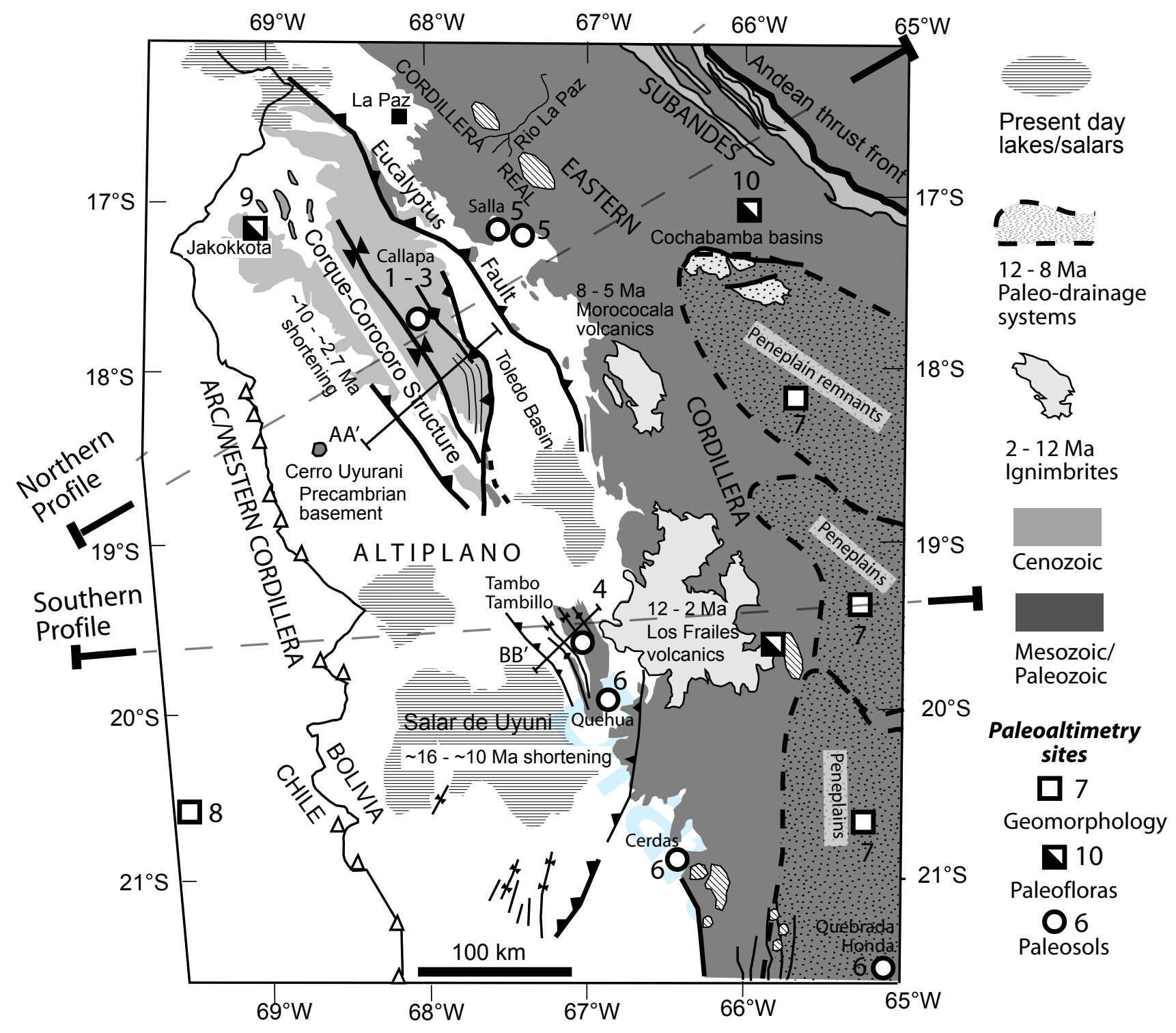




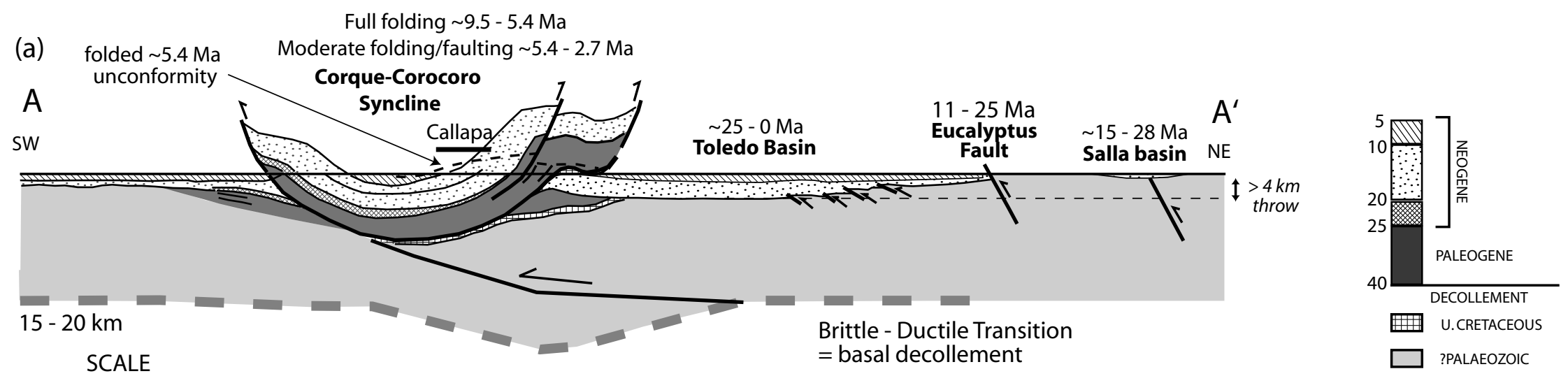

$0 \quad 510 \mathrm{~km}$

Vertical $=$ horizontal scale $\quad 28 \pm 7 \mathrm{~km}$ shortening across Corque - Corocoro basin since $\sim 9.5 \mathrm{Ma}$

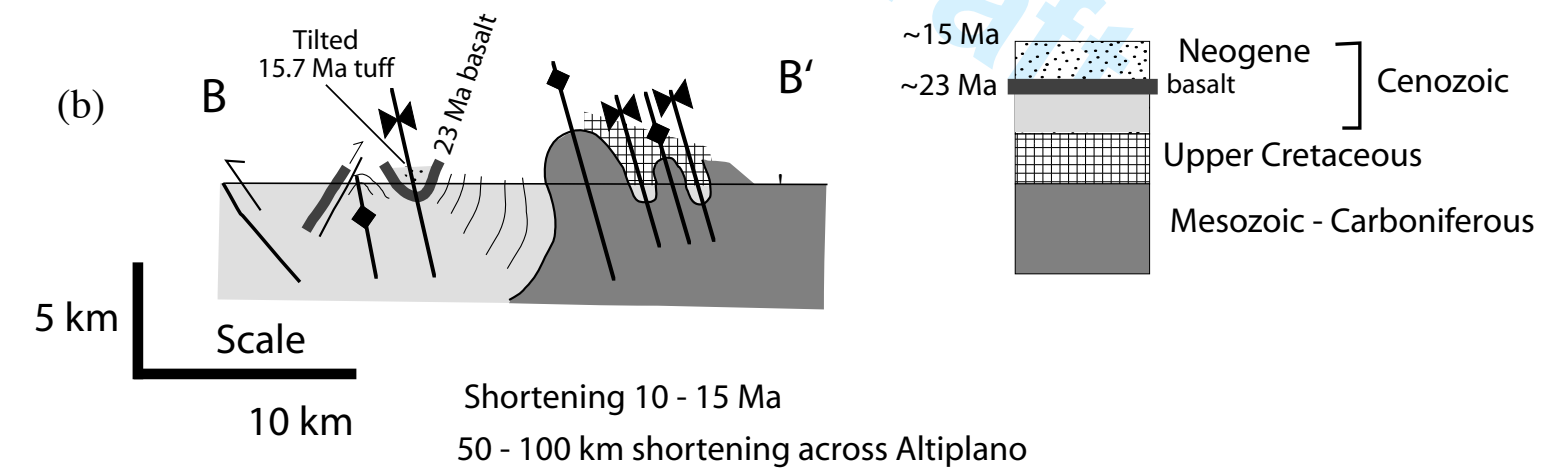


(a)

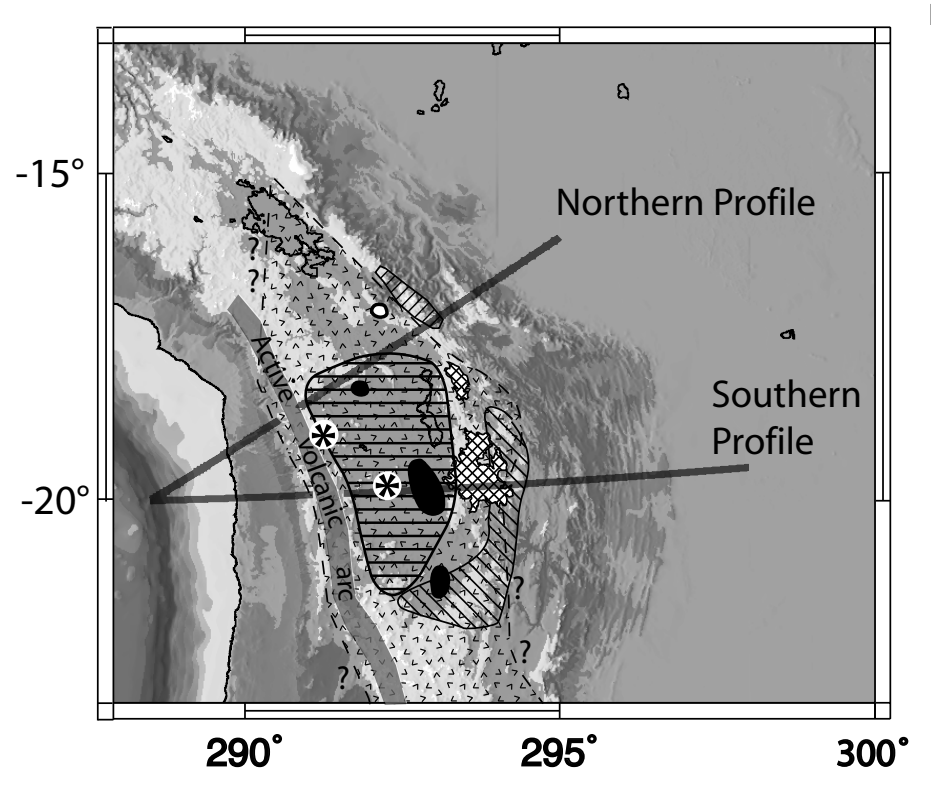

(b)

Normalised
${ }_{3} \mathrm{He} / 4 \mathrm{He}$

${ }^{3} \mathrm{He} / 4 \mathrm{He}$ ARC

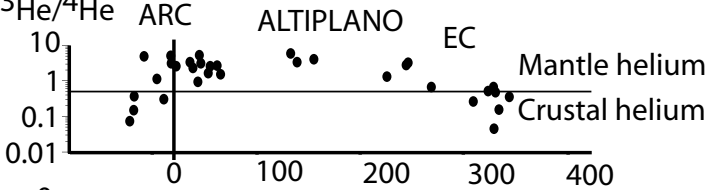

Zone of active mantle melting

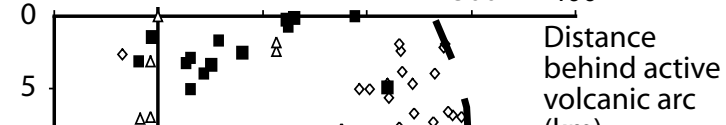

(5)

mantle helium emissions ( $>0.5 \mathrm{R} / \mathrm{Ra}$ )

* Peak mantle component ( $>80 \%$ of gas $=5-6 \mathrm{R} / \mathrm{Ra}$ )

- $3-5$ mafic lavas

$2-12 \mathrm{Ma}$ ignimbrites
$11-13 \mathrm{Ma}$ shoshonites
20 - 25 mafic lava flows/intrusions
+ Granite

Dacite to rhyolite (+ignimbrites)

$\triangle$ Andesite

- Mafic (basalts + shoshonites) 


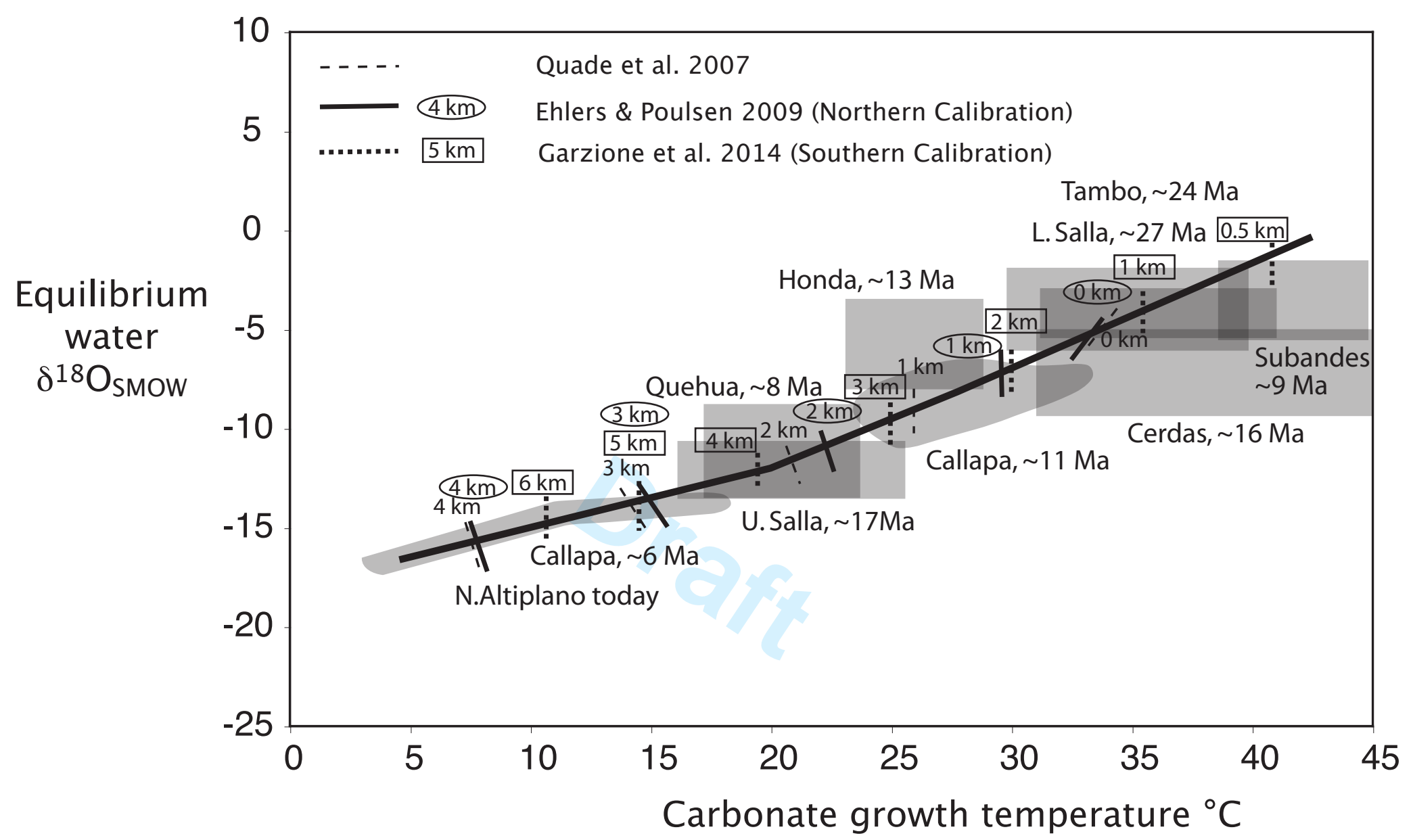


a)

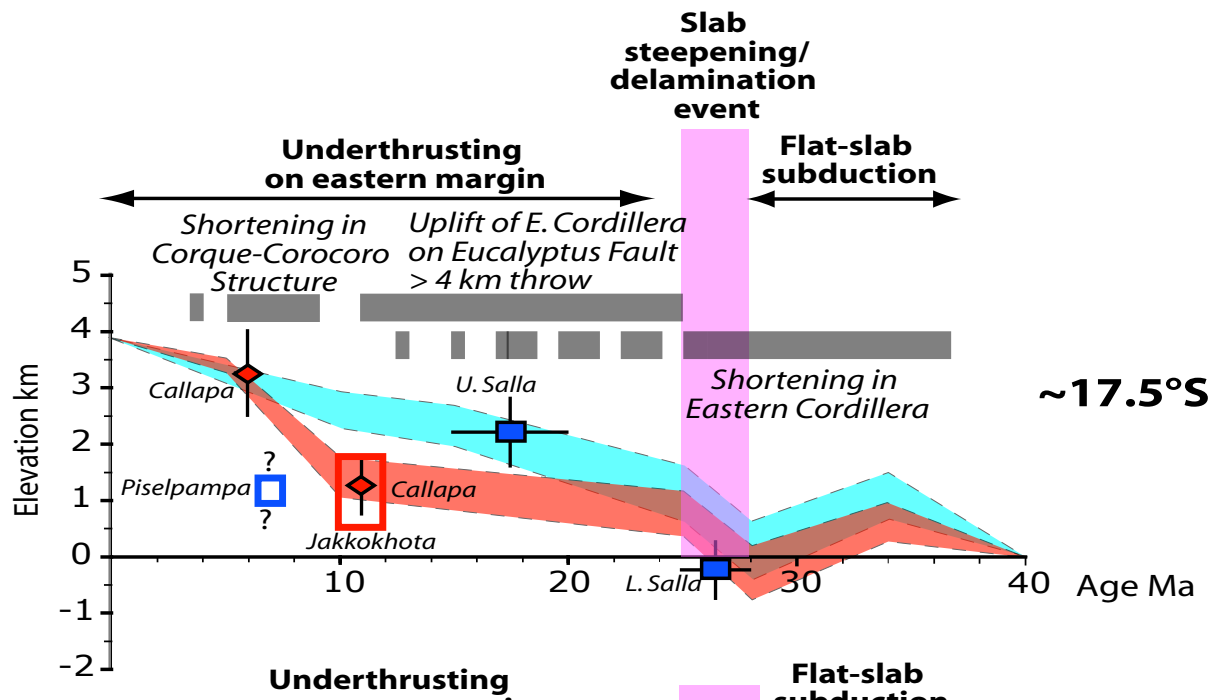

b)

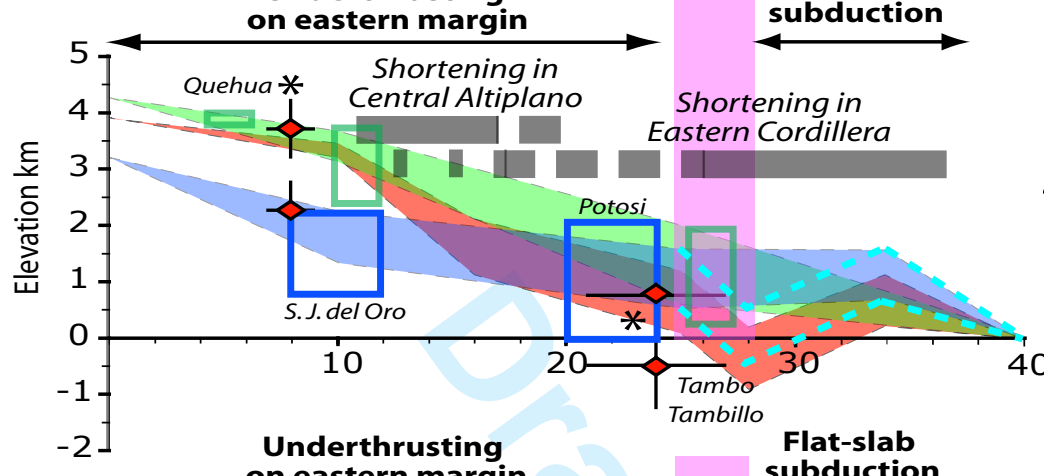

C)

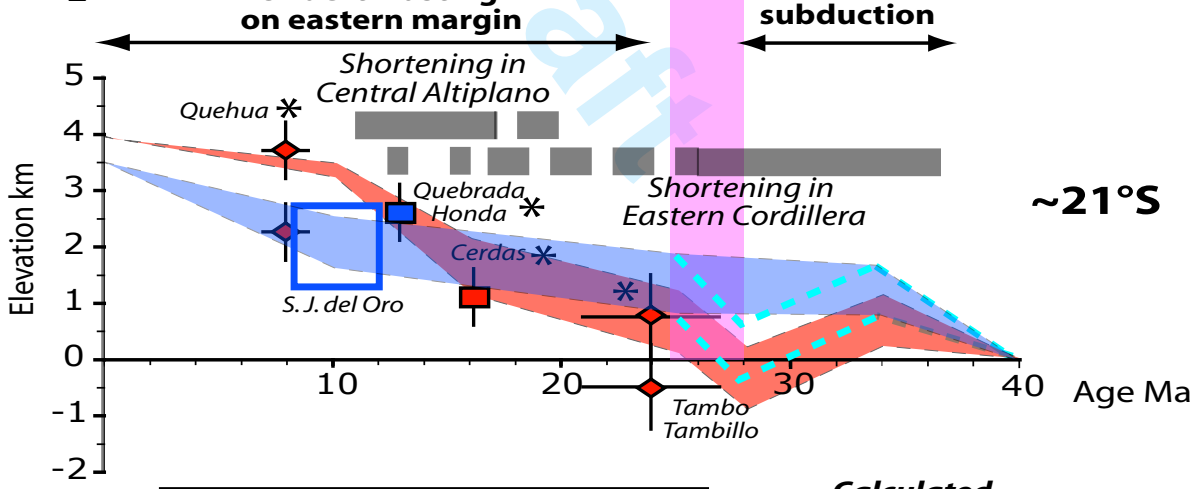

Paleoelevation data

Altiplano (A) paleosol

Eastern Cordillera

(EC) paleosol

Southern

A EC WC Paleoflora

or paleosurfaces

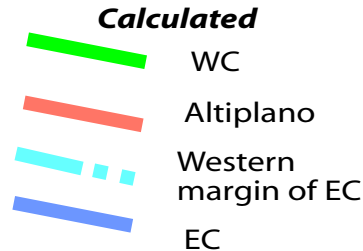


(a)

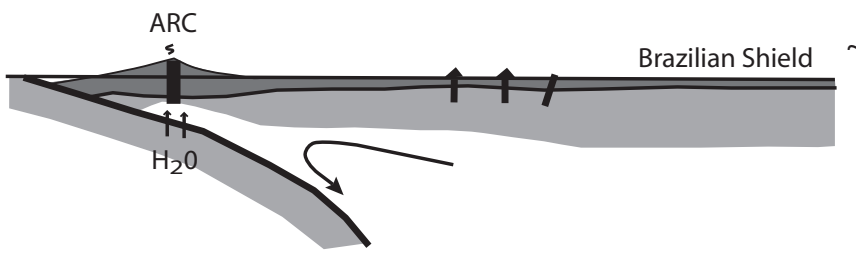

$\sim 60 \mathrm{Ma}$

(b)

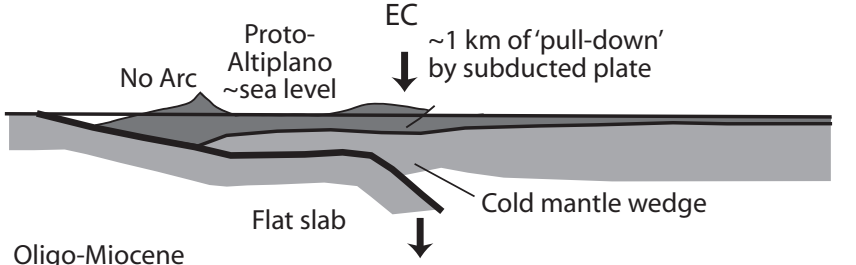

behind arc mafic

volcanics

Altiplano $\sim 1 \mathrm{~km}$

(c)

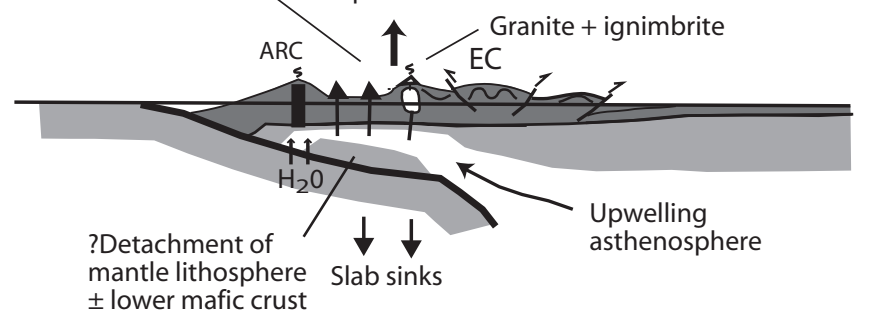

mantle lithosphere
+ lower mafic crust

$$
\begin{aligned}
& \text { Shortening and rapid uplift between } \\
& \text { 9.5 - 2.7 Ma in northern Aliplano, } \\
& 16-10 \mathrm{Ma} \text { in southern Altiplano }
\end{aligned}
$$

(d)

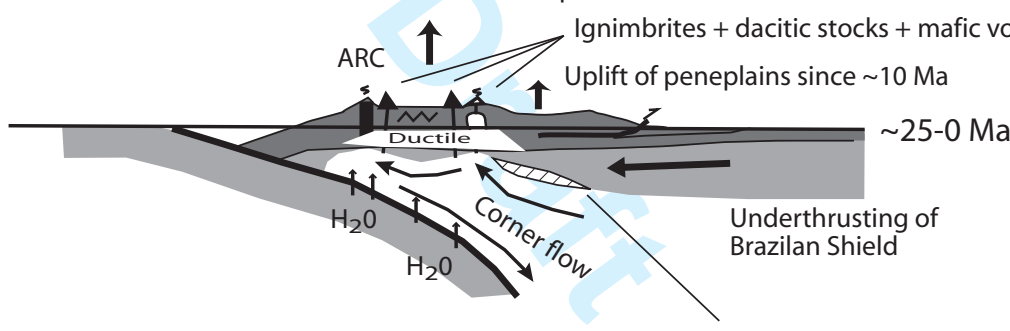

Possible continual or episodic

removal of edge of lithospheric mantle

by corner flow 